The points of the six screws, $X, Y$, and the center of gravity of the beam should be nearly in the same plane; the delicacy of the balance is increased by screwing down the two screws, $\mathrm{X}$; if they are too low, however, the beam will overbalance on either side and will not rise. The balance should be adjusted once for all, best when weighted; a pointer with small adjustable weight may be added, if desired.

W. LASH MilLER.

\title{
REVIEW.
}

\section{SOME ABSTRACTS FROM RECENT FOREIGN LITERATURE UPON INDUSTRIAL CHEMISTRY.}

\author{
BY FRANE H. THORP. \\ Received February 2, I905.
}

IN THE preparation of this article the purpose has been to bring together some of the papers published in the foreign journals during the past year, and which have not been included in the Reziew of American Chemical Research. In the interests of brevity exhaustive reviews have not been attempted and only the more prominent points have been touched upon. Several articles are the continuation of work abstracted in this Journal, 26, 192.

TECHNiCAL EdUCATION.-The teaching of Industrial Chemistry and Chemical Engineering contintues to receive much attention in papers and addresses before scientific societies. Frequent references to it were made by Sir William Ramsay during his tour of this country last summer, and by other authors in papers read at the St. Louis Congress for Applied Chemistry. The subject was also referred to; and an extended review of the situation in America appears in the reports of the Mosely Educational Commission, issued early in 1904 . Procter ( $J$. Soc. Chem. Ind., 1904, 1074) discusses the relation of the University to Technology in his annual address to the Yorkshire section of the Society of Chemical Industry. Dealing with the question mostly from the British standpoint, he finds conditions in England unsatisfactory and insists that fees are generally too high, and that the scholarship system in vogue in that country does not meet the necessities of the case. He doubts the value of the teaching in the ordinary trade schools and evening classes. More attention to technical research should be required in the universities, and manufacturers should offer more inducements for men to take up chemical technology by better remuneration and opportunity for individual experiment in the works.

Progress in the Chemical Industries.-Moulton ( $J$. Soc. Chem. Ind., 1904, 1063) considers the trend of invention in chemical industry under three heads: (I) The products; (2) the sources of material; (3) the processes of chemical industry. Concerning 
new products, he finds many special ones are being introduced to meet peculiar and unusual requirements, especially in explosives and in the coal-tar products industries. Artificial indigo is instanced as making rapid advances and seriously threatening the natural dyestuff. Pharmaceutical products are especially prominent at present among the newer chemical manufactures, and it is predicted that rapid advances in discovery and technology of new drugs may be expected in the near future. The production of synthetic or artificial foodstuffs is another actively growing field of industry. Preservatives of food articles and the conversion of waste materials into forms capable of assimilation are the two chief lines along which advances in these industries are looked for. The difficulties connected with the use of preservatives are very great, and as yet have not been overcome, but there is good prospect of advance in this direction. Little change is likely to occur in the demands upon the sulphuric acid and alkali industries, but the production of cyanides is rapidly extending and the old methods of manufacture are giving way to new processes. Concerning new sources of material, industrial uses for atmospheric nitrogen seem to be a very promising field for investigation; at present only combined nitrogen is of much importance, and the extended use of internal combustion engines is looked upon as giving impetus to the processes which yield ammonia as a by-product in the making of gas for such engines, and to the recovery of nitrogen from the waste products of the combustion. The work of Dr. Mond along these lines is cited as great and far-reaching in its character. In this same connection are to be grouped the efforts to utilize peat and recover its nitrogen content. The utilization of bacteria as a means of fixing atmospheric nitrogen is one of the most recent lines of advance. Preference will be given hereafter to large sources of comparatively low-grade materials, depending upon improvement in plants and increase of skill for economical production. Large scale operations are characteristic of the newer developments in industrial chemistry. In the processes employed most new inventions are in the direction of increasing yields or of utilizing new by-products. Much importance is attributed to "slight variations in surrounding circumstances" as affecting the increase or failure of manufacturing processes; inventors and investigators must give attention to rendering more certain and complete the reactions and processes which are now uncertain, owing to unknown reactions taking place, or to progressive increase of unsuitable reactions. Certainty and uniformity of conditions throughout the process are essential. Comparisons drawn from various industries illustrate this point. The author expresses disappointment at the slow advance of electrochemical reactions in organic chemical manufacturing. The electric furnace is, however, becoming the basis of important industries; it 
is especially adaptable to endothermic reactions, and the heat can be directly concentrated where desired and readily controlled. The step from the discovery of a process to its commercial utilization is often very difficult, and frequently takes rank of itself as an invention. A lengthy and interesting discussion of the paper followed.

Metallurgy.-Beilby (Electrochem, and Metall., I904 (3), 806) has " a new theory of the hardening of metals by plastic flow." He finds two distinct solid phases-the hardened or amorphous, called the A phase; and the annealed or crystalline, called the $C$ phase. The $A$ phase passes into the $C$ phase by the agency of heat, and the $C$ phase passes into the $A$ phase by mechanical flow. Between these are two intermediate mobile phases called $\mathrm{M}$ and $\mathrm{M}^{\prime}$. The facts upon which this theory is based are: (I) Very distinct mechanical properties in the phases A and C; (2) the microstructure in the several phases; (3) the optical properties of the phases $A$ and $C$; (4) the electrical properties of these phases; (5) the thermochemical properties of the phases $A$ and C. The several phases were studied by silver in the metallic state, the properties of which are enlarged upon. Application of the theory is made to certain conditions in the operation of wire drawing, rolling and hammering. Gray (Electrochem. and Metall., I904 (3), 501) has investigated the cause of certain explosions of casks of ferrosilicon, which had stood on a wharf for several weeks. As only o.I per cent. of calcium was present in the alloy it did not seem probable that calcium carbide could have caused the trouble; but considerable amounts of phosphorus and arsenic were found, and also hydrides of these elements were in the gases in the casks; hence the author thinks these gases may have caused the explosion. Dupré and Lloyd (Iron and Steel Inst., May 5, 1904) investigated the same explosions and found that the powdered material liberated a gas when wet, consisting mainly of hydrogen phosphide, which, with air, formed an explosive mixture. Explosion probably resulted from friction between the lumps, or from spontaneous ignition of the phosphoretted hydrogen liberated from a cavity in a lump, through fracture. It is suggested that the drums be filled in with paraffin oil of high-flash test. Gin (French Patent No. 334132, 1903) proposes to manufacture aluminum by reducing aluminum chloride with sodium-zinc alloy. The sodium-zinc chloride produced is used in the fused state as electrolyte to regenerate the sodiumzinc alloy. Wust (Stahl u. Eisen, 1904, (24) 28) publishes the results of experiments in a large way with varying quantities of limestone in the charge for a cupola furnace. The total amount of metal melted in each case was from 15,000 to 20,000 kilos, and eleven runs were made. The proportions of the charge were: 500 kilos of pig iron, 30 kilos of coke, and limestone varying from none to Io kilos. The limestone was supposed to slag 
the ash of the coke and carry some of the sulphur of the fuel into the slag. Increase of limestone to about 9 kilos reduced the sulphur in the metal nearly one-half; no special effect on the phosphorus and manganese was observed; the silicon varied irregularly. In the slag the lime content, of course, increased, but the manganese and iron decreased a little; the alimina fluctuated much, and this was attributed to action on the furnace lining. The silica, in general, decreased, but in a few exceptions a rise took place. The sulphur varied much, and apparently without connection with the amount of limestone used. It is suggested that the amount of sulphur in the slag is influenced by the temperature and viscosity of the fused slag itself. The mechanical loss of iron, manganese and silicon in the slag increased with the increase of limestone, but was generally less than is commonly supposed, being only about I.6 per cent. in the highest total. The metal attains an increased resistance to shock and in tensile strength, and becomes stiffer as the limestone charge is increased, up to 6 or 8 kilos. Surzycki (Stahl u. Eisen, I904 (24), I63) describes the making of open-hearth steel in a continuous furnace, as worked in Russian Poland. The furnace, holding about 50 tons, is provided with two tap-holes, one higher than the other, through which about one-half of the contents of the furnace can be drawn off, leaving a large bath of molten metal on the hearth, into which the next charge is poured. Lime is used to dephosphorize the metal, and during the tapping ferromanganese and charcoal are added in the ladle. These cause a vigorous reaction, which is soon over, and the metal is ready to cast into ingots. After a ten-day or two weeks' run in this way the lower tap-hole. is opened and the hearth emptied; the cycle of operations is then repeated. D. Baker (Iron and Steel Metall., 1904 (7), 21) states that the Otto-Hofiman coke-oren gas was found unsuited to use in the open-hearth furnace, but by injecting some coke-oven tar along with the gas, or by using tar alone, very good heat was obtained. About one pound of tar was equivalent to 12.52 feet of gas, but I,952 pounds of tar were necessary to equal 1,076 pounds of coal, used to furnish producer gas. The sulphur introduced from tho coal was, however, much in excess of that from the coke-oven gas and tar. Cowper-Coles (Electrochem. and Metall., r904 (3), 828 ) has a new method of protecting iron and steel from corrosion by heating it to $500^{\circ}-600^{\circ} \mathrm{C}$., while enclosed in an air-tight receptacle, which is coated with graphite and filled with zincdust. The thickness of the zinc coat depends on the temperature and the time of heating. This new method of dry galvanizing is called Sherardizing. It is claimed that the whole of the zinc-dust is utilized, and that the iron is not materially weakened, as in the case of the fused zinc-bath, and as the temperature is about $200^{\circ}$ lower the temper of steel wire and similar forms is not reduced. Illustrations of the apparatus accompany the 
paper. Copper is claimed to be case-hardened by the process. Leo (Chem. Ztg., I904 (28)) describes the Monell process of steelmaking. It is a modified Martin basic process, taking melted iron direct from the blast-furnace and mixing it with limestone and iron ore. The phosphorus, silicon and manganese go into the slag, leaving the steel nearly free. More ore is added and the metal further heated until the carburization is at the proper point. Berthelot (Compt. Rend., I904 (I38), II53) has calculated the melting temperature for gold, using formulae which he has worked out, and applying them to the data of Holborn and Day, Jacquerod and Perrot and himself. The figures are I064. $3^{\circ}$, I067.4 and I065.6 $6^{\circ}$ respectively. Collins (Trans. Inst. of Min. and Metal., 1903) gives a long and complete review of the methods for wet amalgamation of silver ores in Mexico. Kellermann (Ztschr. Berg. u. Hüttenw., 5I, 606) ascribes the cause of difficulties in roasting zinc blende to the formation of basic zinc sulphate, which, when reduced, yields zinc sulphide and oxide besides metallic zinc. The utilization of the sulphur dioxide in the lead chambers is hindered by the presence of firegases and smoke from the furnace. These difficulties could be avoided by using muffle furnaces with hearths one over another, and excluding the fire-gases; each hearth should have an independent air supply to oxidize the blende and burn the sulphur, and the sulphur dioxide should be rapidly drawn out through special outlets. By blowing steam into the lowest hearth, especially at the end of the process, better results are obtained.

FUel.-Doane (Eng. News, I9O4 (52), I4I) has published some observations upon the spontaneous ignition of coal. The danger of spontaneous combustion is largely dependent upon the quantity of moisture in the coal; for a bituminous coal more than 4.75 per cent. of moisture is unsafe. Iron- or steel-covered bins are recommended, and a free passage of air around all sides and under the bin is desirable, but air-chambers through the mass of the coal are condemned as increasing the risk of rapid oxidation. Cracks and open joints in the bins also admit air to the coal with consequent danger. The depth of coal in the bin should not be more than I2 feet in any case.

Electric Furnace Products.-Minet (Electrochem. Ztg., 1903) describes the development and uses of electric furnaces, and gives a long bibliography upon them. A French patent (No. 334684 , 1903), taken by the Chemische-Fabrik. Greisheim-Electron, claims the manufacture of electrodes for electrolytic cells by fusing pyrite cinders or iron oxide in an electric furnace and then casting the fused mass in molds. They are said to have very good conductivity. The same company has taken out another French patent (No. 334685) for the electrolytic production of bichromate from a chromate solution, which is placed in both anode and cathode compartments, and separated by dia- 
phragms. Lead anodes and iron cathodes are used. Netuberger (Ztschr. angew. Chem., I904 (I7), I04, I29) reviews the patents taken for the manufacture of iron and steel by use of the electric furnace. A description of the Neuburger-Minet furnace, with drawings, is included. The advantages of the electrolytic process are: (a) A more uniform and solid steel; $(b)$ different qualities of steel can be made in the same works, with no loss of time in starting or closing out; (c) decreased cost of furnace construction; (d) repairs can be made without stopping the plant, for several reserve furnaces can be rapidly put into operation; (e) interruptions to the working of the furnace are less liable to happen than with the Bessemer or open-hearth plant. Ditz (Chem. $Z \mathrm{tg}$., I904 (28), 167) reviews the formation of graphite by separation of carbon from carbides. The reaction $\mathrm{CaO}+3 \mathrm{C}=\mathrm{CaC}_{2}+\mathrm{CO}$ is reversible at about $I 620^{\circ} \mathrm{C}$, and Frank has utilized this to make crystalline or amorphous carbon from calcium carbide. The graphite made by Acheson from coal contains from ro per cent. down of ash; it cannot be made from the carbon in the charge merely by the heat of the furnace. The presence of the ash in the coal is essential to the graphite formation; it has been recently suggested that the mineral constituents of the coal may act as catalytic substances to cause decomposition of the carbide first formed. Acheson has found that metallic oxides or sulphides in the charge assist the process, but as these are not in the finished graphite the author supposes that carbon monoxide causes the decomposition of the carbides formed from the amorphous carbon, and the oxides of silicon, calcium, aluminum, etc., of the ash. In time the temperature rises to a degree at which more or less of the oxides themselves vaporize, leaving the graphite more or less pure. Dissociation of the carbides also causes the formation of crystalline carbon. The author also considers the reaction between calcitm carbide or acetylene and carbon disulphide and various organic sulphides as promising future methods of removing sulphur from oils, benzene and, perhaps, coal-gas. Free carbon and calcium pentasulphide and hydrogen sulphide are formed in these reactions, which were observed by Sandmann. Moissan and Hoffmann (Ber. d. chem. Ges., I904 $(37), 3324)$ have prepared a molybdenum carbide by electrically heating a mixture of molybdenum, aluminum and petroleum coke in covered crucibles. Its formula is given as MoC, and it is a grayish crystalline powder.

ElECTROLysis AND Electrochemistry.-Steiner ( $Z$ tschr. Elektrochem. I904 (IO), 317) has studied the conditions of working in the "bell process" for electrolysis of salt. The process depends upon the addition of fresh brine to the anode compartment and upon the effect of increased density in the caustic liquor to affect separation of the anode and cathode products; no diaphragm is used. It is highly essential that the brine solution be fed to 
the anode compartment in such a way as to mix with the liquid immediately surrounding the anode, but without flowing into or disturbing the layers of liquid at lower levels. There should thus be found a neutral zone between the caustic liquor of the cathode, and the salt-chlorine solution around the anode. By proper addition of new brine the downward motion of the salt solution prevents the hydroxyl ions from migrating into the anode space, and the neutral zone remains stationary. The weaker the brine and the lower the current density in proportion to the area enclosed by the bell and the greater the concentration in the cathode liquor the higher will the neutral zone stand in the bell, and hence the nearer it is to the anode. In general, this zone should not be less than I $\mathrm{cm}$. below the anode. A lye of 120 to 130 grams potassium hydroxide per liter can be made continuously in large works, with current efficiencies of 85 to 94 per cent., using a current of 2 to 4 amperes per square decimeter of bell area and 3.7 to 4.2 volts; there was above 97 per cent. chlorine in the anode gases. Ordinary carbon electrodes yielded colored products, but Acheson graphite worked well. In the Electrochemist and Metallurgist, I904, 837, appears a description of the Hazard-Flamand process for electrolytic oxygen and hydrogen, with diagrams and descriptions of the apparatus and various data from a works operating at Petit St. Vrain, near Paris. The electrolyte is a 15 per cent. caustic soda solution in distilled water. With an electromotive force of 2.I volts and a current of 242 amperes per cell the yield is 1.8 cubic feet of oxygen per hour and 3.6 cubic feet of hydrogen. The actual working voltage is, however, nearer 2.4 volts. Müller (Ztschr. Elektrochem., I904 (10), 776) finds that the addition of hydrofluoric acid in place of some of the free sulphuric acid gives an increased yield in the preparation of persulphates. No crusts of persulphate should be permitted to deposit on the anode. Müller (Ztschr. Elekirochem., I 903(9), 978) also found on electrolyzing hot concentrated solutions of nitrates at a current density of 0.5 to I ampere per square decimeter that nitrites are produced. At first the current efficiency is about 85 to 92 per cent., but decreases as the amount of nitrite produced increases, owing to the formation of ammonia. With 50 to 60 per cent. yield of nitrite the efficiency is only 40 per cent. Köller and Askenasy (English Patent No. 2315I, 1903) have a method of improving the circulation of the electrolyte by introducing the electrolyte from the side of the anode and causing it to flow in a zigzag path to the cathode compartment, between certain wedge-shaped parts of the diaphragm, the flow of the electrolyte being at right angles to the lines of electrical force and to the direction of diffusion in the diaphragm. Kellner (English Patent No. 20889, I903) proposes to introduce a hot 22 per cent. solution of salt into the anode compartment and cause it to pass through the diaphragm 
as a filter in the bottom of the anode chamber. By suction on the cathode chamber, or by maintaining a higher level of liquid in the anode compartment, the flow of the electrolyte is secured. The asbestos diaphragm is covered with powdered barium sulphate and the flow of the electrolyte is regulated so that it passes the filter-diaphragm at a slightly greater speed than the velocity of the hydroxyl ions moving towards the anode chamber. Elbs and Becker (Ztschr. Elektrochem, I904 (10), 36r) have electrolyzed bisulphites according to the reaction $2 \mathrm{NaHSO}_{3}+2 \mathrm{H}=$ $\mathrm{Na}_{2} \mathrm{~S}_{2} \mathrm{O}_{4}+2 \mathrm{H}_{2} \mathrm{O}$. The process seems favorable for dilute solu1tions, but with concentrated liquors there is a formation of thiosulphate, $\mathrm{Na}_{2} \mathrm{~S}_{2} \mathrm{O}_{4}+2 \mathrm{H}=\mathrm{Na}_{2} \mathrm{~S}_{2} \mathrm{O}_{3}+\mathrm{H}_{2} \mathrm{O}$. It is, however, proposed to use the process by direct electrolysis in the indigo vats, since here the hydrosulphite, as soon as formed, at once reduces some indigo and is again regenerated at the cathode. Freund (Ztschr. angew. Chem., I904 ( 7 ) , 45) describes a graphite-like mass, taken from the iron water-pipes near an electric road in Frankfurt-on-the-Main. Analysis showed the substance to contain free iron, IO.4 per cent.; ferrous silicate, 44 per cent.; ferrous phosphate $\left(\mathrm{Fe}_{3} \mathrm{P}_{2} \mathrm{O}_{8}\right)$, 37.I per cent.; carbon, 8. I per cent. The phosphoric acid and silica originated in the phosphorus and silicon in the iron. An experiment proved the deposit to be the result of electrolytic action. Gray (Sitzungsber. Kgl. pr. Akad. Wiss., Berlin, I903, 1016) has studied the ozone production by the silent discharge in a Siemens apparatus. The yield of ozone per coulomb is constant for each apparatus and is not affected by potential differences between the electrodes; hence the best yield is had when the potential difference will just cause the luminous discharge in the apparatus while passing gas through it. Warburg, by subjecting oxygen to the silent discharge from a point electrode, found that a decreased yield of ozone per coulomb resulted from increased current strength, if the electrode potential was negative; when positive, an increase of current strength gave a larger yield of ozone per coulomb. A discharge between dielectric surfaces yielded four or five times as much ozone per coulomb as with point electrodes. Siemens \& Halske Co. have patented in France (No.335453) a method for the electric production of nitrogen oxides by passing a mixture of oxygen and nitrogen, under several atmospheres pressure, through an electric arc and then passing to absorbers. The mixture then goes through cooling and absorbing apparatus. Benier, in a French patent, proposes to separate oxygen from the air by utilizing its magnetism. An iron or steel drum rotates between electromagnets by which its peripheral surface is magnetized and accumulates oxygen, which is continuously rubbed off into a receiver by a fixed appliance. Namias (Monit. Scient., (18) 487) gives the composition of baths for depositing nickel, copper, silver, gold, brass, platinum and iron. Von Lepel (Ber. d. chem. Ges., 1904 (37), 
7 I2) has studied the yield of nitrogen oxides obtained from air by the flame discharge between a copper wire anode and a carbon cathode. The gases from near the cathode contain relatively more nitric oxide than those near the anode, but at greater distances the conditions are reversed. The formation of nitrogen oxides is ascribed to electrical action rather than to the temperature. The temperature of the air at a fixed distance from the flame increased as the rotation speed of the anode increased (the voltage and amperes remaining constant in the primary circuit); the yield of oxide increased with the temperature up to a maximum, but medium temperature and frequency gave the best yield. Soaking the cathode in caustic potash or copper sulphate improved the yield. By passing the nitrous gases into alkali carbonate solution a mixture of nitrite and nitrate of sodium is obtained, suitable for fertilizer; conversion of the nitrite to nitrate is not necessary for this use. Haber and Brauner (Ztschr. Elektrochem., I904 (I0), 697) have made a careful study of the carbon cell, and the reactions in it between the carbon, iron and fused caustic soda. They show that it is not a primary cell, but is properly an oxygen-hydrogen gas cell. The oxygen is derived from the air by the iron electrode, which becomes passive in the fused caustic and thus acts as an oxygen electrode. The carbon reacts with the fused caustic to form sodium carbonate, while hydrogen is evolved, thus producing the current. After extended careful measurements of potential at the two electrodes the authors concluded that the cell gives little promise of commercial utility. Friessner ( $Z$ tschr. Elektrochem., 1904 (10), 265) finds that alkali sulphites, subjected to electrolytic oxidation in neutral solution, yield sulphate and dithionate at the anode. Acid solutions do not react thus, but form hydrosulphite and thiosulphate at the cathode. A high potential at the anode, especially if accompanied by a rise of temperature, is favorable to the formation of dithionate, but high current density retards the process. Fontana and Perkin (Electrochem, and Metal., 1904 (3), 656) have studied the electrolytic oxidation of anthracene. Owing to the relative insolubility of anthracene in water and other liquids, an emulsion of it in 20 to 30 per cent. sulphuric acid was tried; the amount of oxidation was very small, both in cold and in hot suspensions. Then a mixture of a solution of anthracene in acetone, with dilute sulphuric acid, was electrolyzed in the anode compartment, using platinum electrodes. On standing over night, after the electrolysis, anthraquinone crystals were obtained. Oxidation in alkaline solution resulted in some anthraquinone formation, but the yield was not so good as in acid liquors. Agitation of the electrolyte improved the oxidation in all cases. In the acetone electrolyte, only 50 to 55 per cent. of the anthracene could be oxidized. Petroleum and pyridine solvents gave unsatisfactory results. The addition of oxygen-carry- 
ing substances, such as salts of chromitum, magnesium and cerium, in acid solution, accelerated the oxidation, but the highest yield of anthraquinone was only about 80 per cent. The solutions were kept at near $75^{\circ} \mathrm{C}$; higher temperatures caused excessive frothing. By using a relatively small cathode surface, and a large anode, the diaphragm could be omitted, and the results remain about the same. The cathode was rotated rapidly, and served to stir the cell contents. The current density used was I ampere per square decimeter at the anode, and at the cathode it was I2 amperes; the voltage was 2.9 to 3.5 . It is concluded that in large works, no diaphragm would be satisfactory, since the migration of the sulphate ions in to the cathode space, would increase the acid concentration at the anode, while the cathode liquor loses strength. Reference is made to the German patent (No. 729502), of Moest, for the electrolytic oxidation of anthracene, using cerium salts as an oxygen carrier. Current density of 5 amperes per square decimeter, at 2.9 to 3.5 volts, is used. Möller (Elektrochem. Ztg. (Io), 199) has reduced nitro-compounds of the naphthalene, anthracene, and phenanthrene series by electrolysis. It appears that the nitro bodies are reduced to amino compounds at once, and no intermediate products were found.

Acids, Salts, Etc.-Taylor (Lit. and Phil. Soc., Manchester, Jan., I904) describes a method for making hydrobromic acid in a large way. A bromide is mixed with some amorphous phosphorus and a little water. Concentrated sulphuric acid is added and heat applied. The hydrobromic acid is evolved free from bromine, but containing traces of sulphurous acid. Spence and Craig have patented (English Patent Nos. 22 I I and 2223, 1903) a method for recovery of bichromates from waste liquors containing ammonium chromate. The solution is treated with lime to precipitate calcium chromate and set free ammonia, which is recovered. The calcium chromate is suspended in a solution of potassium carbonate, and ammonia and carbon dioxide passed in.

The mixture of ammonium and potassium chromates is boiled until the ammonia is driven out, and potassium bichromate results. Lebeau (Compt. Rend., I903 (137), 1255) has studied the dissociation of alkali-metal carbonates, and finds that all of them dissociate when heated in vacuo to $800^{\circ} \mathrm{C}$.; the resulting oxides are volatile at this temperature. Lithium carbonate appears to dissociate more readily than sodium carbonate, but caesium and rubidium carbonates dissociate more easily than potassium carbonate. Bauer (Chem. Ztg., I903 (27), 1268) describes the modifications which were necessary in the process of separating potassium chloride from a mixture of carnallite, sylvine, and so-called "Hartsalz," when the works attempted to use "Hartsalz" alone, and when mixed with other salts. The usual solvent was motherliquors from previous crystallizations containing common salt and potassium chloride. This solution, agitated and heated with raw 
materials until the concentrated solution reaches I. 3 specific gravity, is then settled, decanted and cooled to crystallize. The crystals test about 84 per cent. potassium chloride. Heating by steam coils is recommended because of the more exact control possible. Witt and Ludwig (Ber. d. chem. Ges., I903 (36), 4384) have found that barium nitrite can be made from sodium nitrite and barium chloride with nearly 85 per cent. of a theoretical yield of twice crystallized salt. On large scale work, the yield would undoubtedly be much better. An excess of Ioo per cent. of sodium nitrite over the theory is used, which caused the sodium chloride to "salt out" of the solution, since the salts have a common ion. The mixed sodium nitrite and barium chloride are run into a boiling solution of an equal weight of sodium nitrite; the sodium chloride is filtered from the hot liquor, and the filtrate, on cooling, deposits crystals of barium nitrite; the mother-liquor is boiled again and a new charge of salts introduced. Barium nitrite is stable up to I $5^{\circ} \mathrm{C}$., and is used for diazotizing amines in sulphuric acid solutions, whereby the filtered solution of the diazotized compound, is free from inorganic salts. It can also be used to form other metallic nitrites by double decomposition with sulphates. The process seems to be promising as a commercial method of preparation. Hardwick ( $J$. Soc. Chem. Ind., I904, 2 I 8 ) describes a professional experience in dealing with a sulphuric acid plant which had gotten into "difficulties," owing to the large amount of arsenic in the ore. So much arsenious oxide was formed that the tower acid became saturated with it and the Gay-Lussac tower became clogged, owing to its separation through the filtering action of the coke. The hotter and stronger the acid, the more arsenious oxide it dissolves in the Glover tower. The remedy finally adopted was oxidation to arsenic oxide by treatment with nitric acid, $\mathrm{As}_{2} \mathrm{O}_{3}+2 \mathrm{HNO}_{3}=\mathrm{As}_{2} \mathrm{O}_{5}+\mathrm{H}_{2} \mathrm{O}+\mathrm{N}_{2} \mathrm{O}_{3}$. The arsenic oxide being more soluble in sulphuric acid, did not separate; the nitrogen trioxide remains dissolved in the strong acid and is recovered. Details of the working of the method are given. The arsenic oxide remained in the acid, as an arsenic-free product was not required, but merely that a highly arsenical ore should be utilized. Küster (Chem. Ztg., I904 (28) I.32) gives some results upon a study of the hydrates of nitric acid. By a study of freezingpoints of acid of increasing strengths, two maxima were observed, corresponding to $\mathrm{HNO}_{3} \cdot 3 \mathrm{H}_{2} \mathrm{O}$ and $\mathrm{HNO}_{3} \cdot \mathrm{H}_{2} \mathrm{O}$; also three minima, These hydrates were obtained as solids and as liquids; the monohydrate is the less stable of the two. Carpenter and Linder (J. Soc. Chem. Ind., I904, 577) have continued their study of the Claus reaction in plants connected with gas-works, giving particular attention to the sulphur loss. Complete details of numerous tests upon inlet and exit gases from the kiln, the amount of ammonium salts in the recovered sulphur, and the effect of cyanogen compounds in the gases in the production of the ammonia are all 
considered. The article does not admit of a satisfactory short abstract. Inglis (J. Soc. Chem. Ind., I904, 643) has attempted to trace the loss of niter in the chamber process by subjecting the exit flue gases to fractionation from the liquefied gases at low temperature. The flue gases may contain nitrogen, oxygen, nitric oxide, nitrogen peroxide, nitrous oxide, sulphur dioxide and vapors of sulphuric acid. By cooling to $-185^{\circ} \mathrm{C}$., in a spiral worm, it was found that these gases, except the nitrogen and oxygen, became non-volatile solids, although the nitric oxide still has a slight vapor pressure and could not be completely separated from the nitrogen. By fractionation at proper temperatures the several solids were separated into the groups: (I) nitrogen and nitric oxide; (2) nitrous oxide and carbon dioxide; (3) sulphur dioxide; (4) nitrogen peroxide and sulphuric acid. These were then analyzed. The total volume of flue gas examined was 284 liters. About 0.002 per cent. of nitrous oxide was found in each trial; sulphur dioxide amounted to 0.02 per cent., if the gases had been washed with oil of vitriol; otherwise none was found; about 0.02 per cent. nitric oxide was present, but this was not exact owing to the vapor-pressure. Assuming this loss to be equal to the quantity found, the total amount of nitric oxide in the flue gases was 0.04 per cent., carbon dioxide, 0.05 per cent., and sulphuric acid about 0.008 gram per liter of gases. Nitrogen peroxide is difficult to estimate, as it acts on mercury, and had to be determined by difference; it was determined as about 0.03 per cent. of the flue gases. Taking the total of the nitrogen peroxide and nitric oxide they amount to 0.07 per cent. of the gases, but the total loss of niter in the system (about 3 per cent. of that used) represents only o. I per cent. in the exit gases, hence it is concluded that the loss is due to inefficient action of the Gay-Lussac tower, and may be considered a mechanical loss. In the report of the chief inspector of alkali works for 1903, it is stated that the bottom inlet for vitriol chambers, described by Porter ( $J$. Soc. Chem. Ind., I903, $4 ; 7)$, has been tried in several works, one showing a 7 per cent. increase of yield of acid, and a decrease of niter consumption equal to I per cent. A method of utilizing the waste arsenic sulphide mud from the purification of sulphuric acid is much to be desired. Trautz (Ztschr. physik. Chem., I904 (47), 513) has published a very long and detailed investigation upon the physical chemistry of the lead chamber process for sulphuric acid. A very complete bibliography of previous investigations on the process is given and some of the unsolved problems are stated When an indifferent gas is passed through solutions of nitrosulphonic acid, in different concentrations of sulphuric acid and water, the sulphonic acid decomposes more quickly in the more dilute acid, at temperatures of $25^{\circ} \mathrm{C}$; a mixture of nitric oxide and nitrogen peroxide is evolved, the amount of the latter being greater 
with the more concentrated sulphuric acid solutions. The hydrolysis of the nitrosulphonic acid in concentrated sulphuric acid was measured, but in the dilute solutions the speed of hydrolysis was too rapid for accurate measurement. The following reactions are proposed as representing what takes place in the lead chambers: (I) $2 \mathrm{NO}_{2} \cdot \mathrm{SO}_{3} \mathrm{H}+3 \mathrm{SO}_{2}+2 \mathrm{H}_{2} \mathrm{O}=2 \mathrm{NO}\left(\mathrm{SO}_{3} \mathrm{H}\right)_{2}+\mathrm{H}_{2} \mathrm{SO}_{4} ;(2) \mathrm{NO}\left(\mathrm{SO}_{3} \mathrm{H}\right)_{2}$ $+2 \mathrm{NO}_{2} \cdot \mathrm{SO}_{3} \mathrm{H}+2 \mathrm{H}_{2} \mathrm{O}=3 \mathrm{NO}+4 \mathrm{H}_{2} \mathrm{SO}_{4}$; (3) $2 \mathrm{NO}+\mathrm{O}_{2}=2 \mathrm{NO}_{2}$. The author considers Raschig's theory as the most satisfactory, but admits that the important reaction (I) and the compound $\mathrm{NO}\left(\mathrm{SO}_{3} \mathrm{H}\right)_{2}$, nitric oxide disulphonic acid, have not been observed in practical working. The very elaborate and extended series of experiments carried on by the investigator, are not adapted to satisfactory condensed abstraction. Raschig ( $Z$ tschr. angew. Chem. I904 (I 7) I 398) publishes a long explanation of his theory of the chamber process. From a study of the reactions between nitrites and bisulphites, and of nitrous acid on sulphurous acid, the author published, many years ago, certain equations as expressing the chamber reactions, as follows: (I) ON.OH+ $\mathrm{H} . \mathrm{SO}_{2} \cdot \mathrm{OH}=\mathrm{ON} \cdot \mathrm{SO}_{2} \cdot \mathrm{OH}+\mathrm{H}_{2} \mathrm{O} ;$ (2) $\mathrm{ON} . \mathrm{SO}_{2} \cdot \mathrm{OH}+\mathrm{ON} \cdot \mathrm{OH}=$ $\mathrm{SO}_{2}(\mathrm{OH})_{2}+2 \mathrm{NO} ;(3) 2 \mathrm{NO}+\mathrm{O}+\mathrm{OH}_{2}=2(\mathrm{ON} . \mathrm{OH})$. From his more recent studies of the question, he regards these as confirmed, but admits some uncertainty as to the second; it is possible that the nitrososulphonic acid may not be oxidized directly to sulphuric acid and nitric oxide but some pernitric acid may be formed, thus: $\mathrm{ON} . \mathrm{SO}_{2} . \mathrm{OH}+6(\mathrm{ON} . \mathrm{OH})=6 \mathrm{NO}+\mathrm{H}_{2} \mathrm{SO}_{4}+\mathrm{HNO}_{4}+2 \mathrm{H}_{2} \mathrm{O}$. Since this is very unstable, it decomposes at once into nitric acid and nitrogen peroxide. Divers ( $J$. Soc. Chem. Ind., I904, I I 78 ) gives an exposition of Raschig's theory of the lead chamber process (see previous abstract). In the discussion of the paper, Professor Tilden considers that the reactions proposed by Raschig have not been proved to be essential to the chamber process. Lunge (Ztschr. angew. Chem., I904 (I7), I659) replies to the statement of Raschig and Trautz (see above abstracts). He considers the reactions of Raschig to be contrary to all experience, and reasserts that both nitrogen peroxide and nitrosylsulphuric acid are present and necessary in proper chamber work. $\mathrm{He}$ holds that Trautz has not given sufficient attention to the discrepancies between Raschig's experiments and the actual chamber conditions. Raschig (Loc. cit., I 777) continues the controversy, but admits Lunge's contention that nitrosylsulphuric acid is present. He maintains that the reactions proposed by himself, are, however, sustained by the facts, as shown by experiment. Kessler has patented an improved cooler for the acid leaving his well-known evaporator, whereby the concentrated acid is brought to a temperature at which it has but little action on lead. At the same time, the acid passing to the evaporator for concentration, is warmed by a heat exchange with the concentrated acid. Lunge and Reinhardt (Ztschr. angew Chem., I904 (17), 1041) have 
continued the investigation upon contact action of ferric oxide and admixtures of it, with other substances, for the production of sulphur trioxide, which was instituted by Lunge and Pollitt (Ztschr. angew. Chem., I902 (I5), I I05). The tube containing the contact mass was heated in an electric resistance furnace, in which close observation of temperature was possible. The influence of temperature was particularly studied, a Le Chatelier pyrometer being used. With pure ferric oxide (burnt pyrites), the action starts at $400^{\circ} \mathrm{C}$, and the maximum is reached at $625^{\circ} \mathrm{C}$, with about 70 per cent. of the sulphur dioxide converted. No effect was noticed when the gases were dried over phosphorus pentoxide and the addition of arsenic trioxide did not appear to increase the conversion over that obtained with pure ferric oxide alone; the results were quite near those of the previous experimenters, with arsenical ferric oxide. A trial with ferric arsenate prepared by precipitation, showed about 70 per cent. conversion of the sulphur dioxide at $625^{\circ} \mathrm{C}$., but ferric arsenite gave much lower figures, though there appears to be some doubt as to the purity of this contact mass. About 55 per cent. of conversion was obtained with arsenic pentoxide at $680^{\circ} \mathrm{C}$.; cupric oxide alone had even less action, and the admixture of small amounts of copper salts seemed to have no effect. Silica, both as amorphous quartz and as crystal, had a distinct catalyzing effect, amounting to ro per cent. conversion, at $700^{\circ} \mathrm{C}$. Hartmann and Benker (Ztschr. angew. Chem., I904 (17), 554) criticize certain statements of Meyer, who compares his tangential chambers with the old type of rectangular chambers for sulphuric acid. He claims a yield in his system of 5 kilos of acid per cubic meter of chamber space per twenty-four hours, corresponding to 7.4 kilos of acid of $\mathrm{I} .58$ specific gravity $\left(54^{\circ}\right.$ Bé.). He puts the corresponding yield of the old process as 2.5 and 3.7 kilos respectively. The authors consider this as abnormally low for well-built, rectangular chambers, and claim that the system must be out of order to produce such a yield. Admitting that Meyer's system requires less lead, they assert that it costs more to erect and keep in repair, and that certain kinds of repairs can only be made by practically shutting down the system. They claim that the tangential circulation is not ideal, that dead spaces exist in the system, and the reactions are not complete. A French patent (No. 335496) claims the manufacture of hydrochloric and sulphuric acids by bringing chlorine, sulphur dioxide, and water in contact, in proper proportions and under suitable control. Hydrochloric acid gas and liquid sulphuric acid are the products. With excess of chlorine, the hydrochloric acid is nearly free from sulphuric acid.

Gas and Illumination.-King ( $/$. Gas. Lighting, I904 (85) 8o) describes some experimental vertical retorts in use at Exeter, Eng. The retorts, improvised from 16 -inch circular retorts, 
have on the top a short tube 6 inches in diameter, in which a rod, carrying two conical plungers, with apices pointing upwards, is worked up and down by automatic gearing. As the top cone rises out of the tube on the up-stroke, fine coal slack runs into the tube on top of the lower cone. On the down-stroke the lower cone passes below the tube and into the retort, the coal resting on it dropping into the retort, the upper cone having again passed into the tube and cut off the feed of fine coal. Thus the coal is fed into the retort continuously, in regulated charges of about 6.5 pounds each. No loss of smoke or flame takes place during charging, and the claim is that over 13,000 cubic feet of gas are obtained per ton of coal, as against ro, ooo cubic feet from the horizontal type of retort. A saving of floor area and brickwork, with a lower temperature of carbonizing and a more uniform quality of gas, are the chief points claimed. Patterson (J. Gas Lighting, 1904 (87), 606) has investigated the effect of barometric pressure and the humidity of the air upon the candle-power of the Harcourt pentane lamp. Two electric lamps of the Fleming-Ediswan type were used as standards, and the pentane lamp was compared photometrically with these under varying atmospheric conditions. Assuming io liters of water vapor per 1000 liters of air and barometric pressure of $760 \mathrm{~mm}$. as normal, a correction formula for the Io-candle-power lamp was deduced, thus :

$$
\text { C. P. }=10+0.066(10-\epsilon)-0.008(760-b) \text {, }
$$

when $\epsilon=$ the humidity and $b$ the barometric height in millimeters. From this it can be shown that variations of $r$ liter of water vapor per cubic meter influence the candle-power 0.7 per cent., and Io $\mathrm{mm}$. fluctuation of barometric pressure affects the luminosity of the lamp about 0.8 per cent. Haber and Richardt (J. Gasbeleucht., I904 (47), 809, 833,864, 877) have analyzed the gases from the inner cone of the Bunsen flame. The water-gas equilibrium $\mathrm{CO}+\mathrm{H}_{2} \mathrm{O} \rightleftarrows \mathrm{CO}_{2}+\mathrm{H}_{2}$ was found to prevail there. The thermoelectric determinations of the temperature of the inner combustion zone were practically the same as those calculated from the composition of the combustion products, using the reaction-isochrore of the water-gas equilibrium. Erdmann and Bedford (Ber. d. chem. Ges., I904 (37), I I 84) prepared pure oxygen by the action of hydrogen peroxide on potassium bichromate in a Kipp apparatus. It was then subjected to cooling by liquid air, suitable precautions being taken to exclude air from the oxygen. The liquid oxygen analyzed 99.8 per cent. oxygen, and the boiling-point was found constant at - I $8 \mathrm{I} .8^{\circ} \mathrm{C}$. The liquid absorbs nitrogen to a large extent, taking up at $-190.5^{\circ} \mathrm{C}$. some 380 volumes of gaseous nitrogen, or 42 per cent. of its weight, and at $-191.5^{\circ} \mathrm{C}$. 460 volumes, or 50 per cent. was absorbed. It thus appears impossible that pure oxygen could be made from 
liquid air by fractional evaporation. Stock (Ber. d. chem. Ges. (37) 1432) refers to the above observations as merely a case of two miscible liquids, and no chemical relation between the substances is shown. Hache has taken a patent in France (No. 334783 , 1903) for a carburetted alcohol, produced by mixing denaturated alcohol with crude petroleum in equal volumes and then distilling off the alcohol. A homogeneous distillate is obtained which has much more luminosity than ordinary alcohol and which does not form noxious vapors, nor leave greasy residues. The material is presumably used as an illuminating oil, or in gas engines. Bodenstein (Ztschr. Elektrochem., I904 (Io), I23) describes a new form of mercury vapor lamp, devised by Dr. Küch; the apparatus is made of fused quartz and has the form of an $\boldsymbol{H}$-tube, with iridium electrodes fused into the vertical tubes. The arm connecting the two vertical tubes is $\mathrm{I} 7 \mathrm{~cm}$. long and slightly inclined. By electrically heating one of the side tubes the mercury vaporizes and the vapor forces the liquid mercury along the connecting tube to the other side tube, making a short circuit. At the moment of contact the heating current is mechanically cut off and the liquid mercury draws back into the vertical tube and the arc begins to burn at once. A current of two amperes at roo volts is used between the two mercury surfaces. The brilliancy is about equal to that of a carbon arc light, and the color is greenish but the light is rich in ultraviolet rays. A strong odor of ozone was noticeable at the beginning of the lamp's operation, but this disappeared as soon as the tubes became hot, the ozone being thus destroyed. Paweck (Ztschr. Elektrochem., 1904 (10), 297) has proposed a new kind of mercury-vapor lamp, in which the lamp is started by having the electrodes connected by mercury before starting and causing them to be separated by throwing the mercury to each end of the horizontal tube by centrifugal force, developed by rotating the lamp when it is in action. Gardner and Dufton (J. Soc. Chem. Ind., I 904, 598) have devised a new lamp (the "dalite") for colormatching. It is an arc lamp, surrounded by a special glass which absorbs those rays from the lamp which are in excess of normal hues present in daylight.

Cyanides.-Feld ( $J$. Gasbeleucht., I904 (47), I32, 157, 179), in a study of the Bueb's process for cyanogen recovery, finds that the cyanide mud contains only one-fourth of the insoluble double ammonium-ferrous-ferrocyanide, one-fourth insoluble iron cyanide and one-half as soluble ammonium ferrocyanide. There is trouble in recovering the ammonia, and the working of the cyanide mud is not adapted to gas-works routine. The author recommends using an i 8 per cent. copperas solution, which is dilute enough to work easily and yet retain the cyanogen as ammonium salt. Körting ( $J$. Gasbeleucht., I904 $(47), 45)$ teports upon the working of Bueb's cyanogen recovery process at the Hanover 
gas works. After cooling to collect tar and naphthalene the gas passes into a sectional washer containing a ferrous sulphate solution of $20^{\circ}$ Bé; the iron is precipitated as ferrous sulphide, which reacts with ammonia and cyanogen to form an insolubleiron-ammonium-cyanide, $2 \mathrm{FeS}+6 \mathrm{NH}_{3}+6 \mathrm{CN}+{ }_{3} \mathrm{H}_{2} \mathrm{O}+5 \mathrm{O}=\left(\mathrm{NH}_{4}\right)_{2} \mathrm{Fe}_{2}(\mathrm{CN})_{6}$ $+2\left(\mathrm{NH}_{4}\right)_{2} \mathrm{SO}_{4}$. This cyanogen mud is pumped out of the washer and collected. It contains about one-third of the ammonia in the gas.

Pigments.-Rohland ( $Z$ tschr. angew. Chem., I 904 ( 1 7), 609) has investigated the constitution of ultramarine and finds it resembles trass and puzzuloana, has hydraulic properties, and if added to Portland cement increases its binding properties. The soda is thought to be in a condition similar to the free lime in Portland cement. The formula $2 \mathrm{Na}_{2} \mathrm{Al}_{2} \mathrm{Si}_{2} \mathrm{O}_{8} \cdot \mathrm{Na}_{2} \mathrm{~S}_{2}$ is proposed, but as the substance is isomorphous with the minerals sodalite, hauyn and nosean, it may have the formula $\mathrm{Na}_{4}\left(\mathrm{Al}\left(\mathrm{NaS}_{3}\right)\right)\left(\mathrm{Al}_{2} \mathrm{SiO}_{4}\right)_{3}$. The colored constituent is thought to be present in small quantities only, and disseminated through the mass in solid solution. McIntosh (Chem. News, I904 (89), I97) proposes to make Venetian red by heating waste peroxide of lead and anhydrous ferrous sulphate to accomplish the reaction $2 \mathrm{FeSO}_{4}+2 \mathrm{PbO}_{2}=2 \mathrm{PbSO}_{4}+$ $\mathrm{Fe}_{2} \mathrm{O}_{3}+\mathrm{O}$. Manganese peroxide may be used and the manganese sulphate recovered. Liebig (Ztschr. angew. Chem., I904 (I 7), I 57 et seq.) has a series of articles upon the manufacture of white lead by the German (chamber) and French (drum) processes, and the preparation of red lead; details of the processes and tests are given.

Cements.-Gemmell ( $J$. Soc. Chem. Ind., r 904, 306) reviews the methods of Portland cement testing. Uniform methods of chemical analysis are considered unimportant, but uniformity in the physical tests is very essential. The methods of making. the usual tests are described. Gary (Mitt. königl. techn. Versuchsanst., I903 (2I) I 59) has made tests of the strength of mixtures of blast-furnace slag and binding material. The strength of such mixtures falls rapidly if kept some time. This is more marked with Portland cement mixture than in those made with lime. A decrease in the specific gravity in the test pieces was also noted. The loss of strength is larger proportionally in the resistance to crushing than in the tension strength.

Explosives.-Will (Ber. d. chem. Ges., I904 (37), 268) has a long review of the progress in manufacturing explosives, from the discovery of gunpowder to the present time. Thomson, in a report upon a nitroglycerine explosion at Faversham, Eng., concludes that the dropping of a lead filter into a tray containing about 3 pounds of the explosive caused the explosion of about 1,000 pounds of nitroglycerine in the washing tank. Various precautions for future safety are suggested. The possibility of exploding nitroglycerine by friction of a rubber shoe on a lead 
surface was investigated, with negative results; sprinkling sand and powdered sulphur on the nitroglycerine and repeating the trials also gave no explosion. Macnab and Leighton ( $J$. Soc. Chem. Ind., 1904, 293) have studied the products and temperature of combustion of some smokeless powders. The ingredients of a number of commercial powders were determined and then the calories and the composition of the gases were found. The temperatures were taken with the thermoelectric pyrometer of Roberts-Austen, using a rhodium-platinum couple inside of the bomb in which 4 grams of each explosive were fired in the presence of air. The deflection of the galvanometer is directly proportional to the temperature.

Giass, PotTery. Etc.-Hertwig (Sprechsaal., igo3 (36), i 845) has experimented on the production of yellow glazes for porcelain. He found that tungsten and molybdenum, in the presence of manganese, gave bright yellow and orange colors when fired in a reducing atmosphere. Manganese peroxide seems to give up oxygen to tungsten at high temperatures, and the color of the glaze becomes reddish yellow or orange. Molybdenum phosphate produced a sulphur-yellow glaze when the biscuit had been treated with manganese chloride. Colloidal tungstic acid yields a range of colors from ivory to orange-yellow after the application of manganese nitrate or chloride, after refiring. Ammonium metatungstate, prepared by heating ammonium tungstate until the evolution of ammonia ceases, furnishes good glaze pigment. Other crystallizable metatungstates, made from nitrates or chlorides, of alkaline earths, or metals, with tungstic acid, can be used in the same way. Certain double salts, made from the alkali metatungstates, by treatment with barium chloride and metallic sulphates, also furnish glaze pigments. Thomason ( $J$. Soc. Chem. Ind., I904, 469) has examined the extent to which lead oxide volatilizes from the glaze mixture in the glost firing of china and the effect of subsequent volatilization from the walls of the saggar upon the leadless glaze ware in the same saggar. It appears that a leadless glaze may gather from 5 to 6 per cent. of lead oxide in firing. The same author also treats of the preparation of lead glazes of low solubility, the object being the protection of the health of the operatives. The fritt of lead glaze used at the Doulton Pottery is a lead bisilicate containing about 65 per cent. lead oxide and 35 per cent, silica. This is fairly insoluble in hydrochloric acid of 0.25 per cent. (approximate acid strength of the gastric juice). It takes up some alumina in the fritting process and loses some lead oxide by rolatilization and absorption in the bed of the kiln. The fineness of grinding of the fritt has considerable influence on the solubility of the lead, but there is no special difficulty in keeping well below the legal limit of 5 per cent. soluble lead oxide. Garros (Compt. Rend., I904 (139), 68) has devised a new "asbestos porcelain," made 
by firing asbestos. The biscuit is quite porous if fired at temperatures not over $1400^{\circ} \mathrm{C}$., and is recommended for filters. Above $1650^{\circ} \mathrm{C}$. the material fuses to a glass. A mixture of asbestos, with alumina and alkali, if fired at about $1500^{\circ} \mathrm{C}$., gives a semivitrified biscuit, very suitable for insulators. A similar mixture, with more alkali and alumina, can be used as a glaze on the biscuit and the insulation is excellent. It is claimed that copper can be fused in with the glaze and attached to the porcelain. Buchner (Ztschr. angew. Chem., 1904 (17), 985) finds that the residue of aluminum oxide from Goldschmidt's alumino-thermal process, when mixed with clay or kaolin for stoneware, gives the pottery great resistance to temperature changes, since it decreases the contraction very much. An increase in tensile strength is also claimed, and the ware is particularly recommended for diaphragms in electrolytic cells. Hopwood (J. Soc. Chem. Ind., $1904,592)$ has ignited various clays in atmospheres of nitrogen, carbon dioxide, steam, oxygen, hydrogen, carbon monoxide, ammonia, marsh gas, olefiant gas and air (limited supply and in excess) with special reference to the color produced in the calcined product. He finds that all clays darken when heated alone, or in nitrogen, carbon dioxide or in steam, but they blacken only when organic matter, in moderate or large amounts, is present. The darkening disappears on oxidation; for white, ivory, yellow or red wares, made from clay having little organic matter, but little air is needed to develop their normal color. The darkening is mainly due to carbon, ferrous oxide or magnetic oxide, with occasionally ferrous sulphide and metallic iron. All clays darken in reducing atmospheres, but this is not noticeable unless considerable iron or organic matter is present. The color becomes lighter or redder in oxidizing atmospheres; hence the makers of blue bricks must exclude air from the kiln during the last part of the heating lest a red-brown color develop.

Photography.-Baekeland (Brit. J. Photog., I904 (54), I46) has studied the retrogression of the latent image before development in exposed plates, films, bromide papers and printing papers of the "velox" class. If kept undeveloped for some time after exposure the image may almost entirely disappear. This change is independent of the developer used and is of a chemical nature. At low temperatures $\left(0^{\circ}-4^{\circ} \mathrm{C}\right.$.) plates showed no sensible change after two weeks, but at $40^{\circ}$ to $48^{\circ} \mathrm{C}$. there was marked retrogression after three days; the change is retarded by keeping the plates in a dry atmosphere over sulphuric acid; presence of acid or chromium salts in the emulsion appear to greatly accelerate the retrogression, but if the emulsion is slightly alkaline retrogression is greatly reduced, even when chrome alum is present. Overexposed plates show little or no change of this kind, but under exposure is especially favorable to it. Retrogression varies considerably with different brands of plates, films and papers, and 
is especially marked in certain kinds of films and papers. In another investigation he finds (Monit. Scient., I904 (I8), 355) that slow drying of the emulsion for developing papers containing insoluble silver salts produces more rapid printing and the image is flatter than if more rapidly dried. If soluble silver salts are present in the emulsion, slow drying causes red prints, which are troublesome to tone and soon fade. Rapid drying in dry air at rather low temperature is best. If the air is too dry, the paper becomes electrically charged in passing over the drying machine and attracts dust specks. The same writer (Loc. cit., 362) recommends a pure silver drum for the centrifugal machine used in filtering silver bromide-gelatin emulsion to avoid contamination with other metals. The cover should not be screwed down, as bits of metallic dust wear from the thread and get into the emulsion. A uniform temperature of $30^{\circ}$ to $35^{\circ} \mathrm{C}$., and uniform and moderate speed are essential; and small and frequent additions of the liquid to be filtered. The bromide is washed in the drum with warm water to remove ammonia, etc. Well prepared silver bromide, kept in a cool place, was found in good condition after two years, being but slightly more sensitive than originally. Witt (Phot. Mitt., I9O4 (4I), 235) states that pyridine hastens the "ripening" of gelatine silver emulsions without causing granular appearance or fog on the plates. It is proposed to sensitize the emulsion with a double salt, pyridinesilver nitrate, $\mathrm{AgNO}_{3} \cdot\left(\mathrm{C}_{5} \mathrm{H}_{5} \mathrm{~N}\right)_{2}$. The emulsion, if used without ripening, gives "slow" plates, which give strong contrasts, but by heating to $100^{\circ} \mathrm{C}$. for a time the emulsion becomes more rapid and still yields good negatives.

Fertilizers.-Wagner (Illust. landw. Zeit., igo3, 959) describes a new fertilizing material, prepared by fusing rock phosphate Ioo parts, sodium bisulphate 70 parts, sand 22 parts, calcium carbonate 20 parts, and coal 7 parts. The fused mass is run into water and the resulting sand is ground very fine. The substance is more soluble than basic slag and is almost as rapid in its effect on plants as is superphosphate. It is not hygroscopic and does not deteriorate on keeping in store. It is called Wolter phosphate.

VARnishes, Resins and Gums.-Tixier and Rambaud (French patent No. 334430, 1903) propose to make varnish direct from the gums, without previous melting by solution in "terpeneol," $\mathrm{C}_{10} \mathrm{H}_{18} \mathrm{O}$, a product of the action of dilute nitric acid on oil of turpentine. By digesting turpentine at $20^{\circ} \mathrm{C}$., with nitric acid of $20^{\circ}$ Bé., crystallizable terpine is formed, which is washed and converted into terpeneol by treatment with dilute sulphuric acid or by distillation with steam. The unmelted gums dissolve in this liquid, or in a mixture of it with turpentine or benzene, to form varnish. For oil varnish a fatty acid which dissolves in the oil is added to prevent precipitation of the gum from the 
terpeneol solution by the neutral oil. Collins (Scientific American, I903 (89), 368) reports upon the details of Thurlow's process for artificial camphor, as worked at Port Chester, N. Y. Anhydrous oxalic acid is heated with turpentine oil in steam-heated pans, forming pinyl oxalate and pinyl formate; the liquid product is distilled with steam in the presence of an alkali and the resulting camphor and borneol mixture is filter-pressed, washed to remove oil and then oxidized to convert the borneol to camphor. The crude camphor is then sublimed for further purifying. Forster (Chem. and Drug., I904 (64), 289) maintains that the bodies called pinyl oxalate and pinyl formate in the Thurlow process for synthetic camphor (see preceding abstract) are bornyl hydrogen oxalate, $\mathrm{C}_{10} \mathrm{H}_{17} \mathrm{O}$.CO.COOH, and bornyl formate, $\mathrm{C}_{10} \mathrm{H}_{17} \mathrm{O}$.CHO, respectively. The former is converted to camphor and the latter to borneol when heated with alkalies, thus : $\mathrm{C}_{10} \mathrm{H}_{17} \mathrm{O} . \mathrm{CO} \cdot \mathrm{COOH}=$ $\mathrm{C}_{10} \mathrm{H}_{18} \mathrm{O}+\mathrm{H}_{2} \mathrm{O}+{ }_{2} \mathrm{CO}_{2} ; \mathrm{C}_{10} \mathrm{H}_{17} \mathrm{O} . \mathrm{CHO}=\mathrm{C}_{10} \mathrm{H}_{18} \mathrm{O}+\mathrm{CO}$. R. G. Smith (J. Soc. Chem. Ind., I904, 105) publishes a long investigation upon the bacterial origin of vegetable gums. He found that bacteria inhabiting the tissues of the trees can form arabin, metarabin, pararabin and other gums. Differences in the physical nature of gums are ascribed to differences in climate, temperatures of formation and the nature of the tree sap. Differences in season would probably affect the activity of the bacteria and thus cause differences of optical properties; e. g., in the same gums from one season to another. Artificial infection of trees is proposed as a method of making them produce more gum; or, as the author puts it, the world's gum supply might be increased if the natives were taught to "sow bacteria and reap gum."

Miscelianeous.-Thos. Tyrer ( $J$. Soc. Chem. Ind., I904, $22 \mathrm{I}$ ) has published a long and instructive argument upon the "Need of Duty-free Alcohol for Industrial Purposes." The conditions apply especially to Great Britain, but the facts and figures will apply to this country in many cases. The extended discussion of the paper by many present, throws much light upon the difficulties from the government standpoint. Sisson ( $J$. Soc. Chem. Ind., I904, 242) describes the production and use of liquefied carbon dioxide. Diagrams of the compressors, coolers, and purifying apparatus, together with the valve for the steel containing flasks, are shown. The gas, after production, is stored in a gasometer, there being a $\frac{1}{2}$-inch layer of mineral oil on the water to prevent absorption of the carbon dioxide by the water. The compression is in three stages: first, to 5 atmospheres, next to I 5 atmospheres, and finally to the necessary pressure for liquefaction. The compressed gas passes through water-cooled copper coils, after each compression. The first compression cylinder is lubricated by a small injection of water, which is separated afterwards; the second and third cylinders are lubricated with glycerine, which is also separated by gravity from carbon dioxide. The 
steel storage bottles are tested by hydraulic pressure, up to 3360 lbs, per square inch. Valves are made from hard brass or gunmetal. The various uses of the liquid are explained. Marshall ( $J$. Soc. Chem. Ind., I904, 645), in a paper on acetone manufacture and purification, attributes the deterioration of commercial acetone on keeping, to the presence of certain basic substances similar to methyl amines, not removed in the purifying. It is suggested that the crude acetone be purified by re-distilling over sulphuric acid, instead of caustic soda as now generally done.

Oils, Fats.-T. E. Thorpe (Proc. Chem. Soc., I904 (I9), I2) has examined butters from various sources and finds that the chemical character of the butter-fat is variable and is influenced by the food, breed and peculiar idiosvncracies of the cow, and also by climatic conditions. Nicloux (Compt. Rend., I904 (I38), II75) finds that the lipolytic substance in castor seeds is the "cytoplasma." It is not yet determined whether this is itself the cause of the hydrolysis of fats, or whether it secretes the ferment. Power and Gornall (Chem. Soc. Proc., I904 (20), 135) have examined the constituents of chatlmoogra seeds, and find they contain a hydrolytic enzyme and a cyanogen body, which react on each other, and form hydrocyanic acid. The seeds yielded 30.9 per cent. of oil, which had a m. p. $22^{\circ}-23^{\circ} \mathrm{C}$; sp. gr. 0.95 I at $25^{\circ}$ and 0.940 at $45^{\circ} \mathrm{C}$. $(\alpha)_{\mathrm{D}}^{15^{\circ}}=+52 ;$ acid value, 23.9; iodine value, I03.2; saponification value, 213. The oil when saponified yielded glycerol, a little phytosterol, and a mixture of several fatty acids, belonging to the series, $\mathrm{C}_{n} \mathrm{H}_{2 n-4} \mathrm{O}_{2}$. These hare not previously been found in fatty oils. The highest homologue of these acids, in the pure state, forms glistening plates of formula $\mathrm{C}_{18} \mathrm{H}_{32} \mathrm{O}_{2}$ (m. p. $68^{\circ} \mathrm{C}$ ) ; this is called chaulmoogric acid. The press-cake of the seeds yielded an oil, $\mathrm{C}_{13} \mathrm{H}_{32} \mathrm{O}_{2}$ (b. p. $2 \mathrm{I} 4^{\circ} \mathrm{C}$.), isomeric with the acid. An extended study of this acid was also made, and many derivatives prepared. Hoyer (Ber. d. chem. Ges., I904 (37), I436) has continued experiments on the decomposition of fats by enzymes. In germinating seeds, the enzyme near the germ appears weaker than that from the other parts of the seeds; but as germination progresses, the activity of the enzyme decreases. The turbid oil expressed from castor seeds after trituration with sand and cotton oil, induced $8 \mathrm{I}$ per cent. of hydrolysis of the latter in three hours. Filtration and removal of turbidity gave an oil without enzyme activity; the residue was highly active. Acidified water was also found suitable for this extraction of the enzyme, but the process does not appear of much value from the technical standpoint. The time of trituration of the castor-seed meal with the oil and with acid water was found to have little influence on the activity. Short, vigorous trituration of the seeds in a paint mill was recommended. The addition of acid appears to be influenced by the quantity of seeds, and a definite amount for each acid tried was found to be necessary; 
above a certain maximum, the addition of acid was injurious, except with butyric acid. The acids tried were formic, acetic, butyric, oxalic, sulphuric, and certain high fatty acids from linseed oil. Carbon dioxide appeared to have no effect. Lewkowitsch (Analyst., I904 (29), 105) has examined almond, peachkernel and apricot-kernel oils, and finds that their constants are not a certain means of differentiating between them. The Bieber test ( 5 parts oil, treated with I part of a mixture of sulphuric acid, fuming nitric acid and water) is considered the most useful, but the reagent must be newly prepared, and is not a safe method of detecting adulteration of almond oil with either of the others. $\mathrm{He}$ is unable to confirm the statement of Tortelli and Pergami, that most of the fatty acids contain lactonic substances in small amounts. Raikow (Chem. $Z$ tg., I 904 (28), 272) has determined the constants of bear's fat. It is white, similar to lard. It has a lower specific gravity and melting-point than fat from the dog, cat, or fox; the iodine value is rather high. Both the kidney fat and the flare fat were examined, and differ slightly, the former being harder and more opaque. A table of constants is given. Lewkowitsch ( $J$. Soc. Arts, I904 (52)) has printed his Cantor lectures upon the "Uses and Applications of Oils and Fats, and upon the Manufacture of Soap and Candles and Glycerine." Fokin (Chem. Rev. Fett. u. Harz-Ind., I904 (I I)), in a number of articles, reports upon the hydrolysis of fats by the enzyme from castor seeds. There is no difference in the action of the enzymes from different kinds of seeds (wild or cultivated). For maximum hydrolysis, the amount of seeds used is the determining factor and not the quantity of water used. The yield of fatty acids is not much affected by the quantity of water used, if the quantity of seeds be large (20 to 40 per cent.) but with small amounts of seeds ( 5 per cent.), varying the quantity of water has considerable effect on the yield, owing to the ease with which small amounts of seed separate from the emulsion. The concentration of the glycerol solution depends on the amount of water used in the emulsion and for washing. The glycerol contains albumins, and must be purified. With correct proportions and conditions a yield of 90 to 95 per cent. of fatty acids in three days, is claimed. Thorough mixing and larger amounts of fat used, give higher yields of fatty acids. The acids thus formed are said to be easily bleached. The glycerol solution is not readily separated from the seed residues. The sulphuric or hydrochloric acid used in the emulsion, must not be stronger than $\mathrm{N} / 20$, and may be as weak as $\mathrm{N} / \mathrm{r} 2 \mathrm{O}$, with large amounts of seeds. All attempts to get the enzyme in solution failed. Pancreatic juice proved too costly and too slow in its hydrolytic action for technical use. It gave products that were inferior to those from castor seed, and the glycerol had to be separated by "salting out," and is not so pure as that separated from soap-lyes. In the same connection the author has examined 
the seeds of about sixty plants and found that more than half of them hydrolyzed fat to the extent of Io to 16 per cent., but only with the fresh seeds. It is not thought that this is due to an enzyme in all cases, since in two species only, did the yield of fatty acids bear any quantitative relation to the amount of seed used. It is concluded that lipolytic enzymes are not confined to any particular plant family.

Health and Sanitation.-Renard (Monit. Scient., igo4 (i 8), 39) reports upon his own suggestion of some years ago, to employ hydrogen peroxide for preserving milk. One or two per cent. of a I2-volume solution, added to milk, decomposes completely in six or eight hours, but larger amounts remain much longer; 5 per cent. added, still showed some undecomposed peroxide after several days. The milk can be kept much longer than untreated milk, without souring. Test samples at $\mathrm{II}^{\circ} \mathrm{C}$., untreated, soured after twenty-four hours; with I per cent. of I 2 -volume hydrogen peroxide, souring was retarded to eighty hours; with 2 per cent., until ninety hours; and with 3 per cent. after ninety-five hours. A similar test at $20^{\circ} \mathrm{C}$., showed souring to occur in much shorter time; viz., after thirteen, twenty-four, twenty-six and thirty-two hours respectively. The peroxide should be added directly after milking, and the milk kept cool for six to eight hours, until the peroxide is decomposed. The odor and taste are said not to be affected, and the milk is claimed to be satisfactory as an infant food. Baker (J. Soc. Chem. Ind., 1904, I59) gives a résumé of the evidence and report of the royal commission on arsenical poisoning, appointed to investigate the epidemic in England, in 1900 and 1902 , caused by drinking beer, made from glucose and malt which were contaminated with arsenic. Malt becomes contaminated at times when dried over a fire made with gashouse coke. It was shown that the epidemic in Halifax was characterized by a peripheral neuritis, which alone, could hardly be distinguished from "alcoholic neuritis." It appears that arsenic is usually eliminated from the body with considerable rapidity, but yet it is to be considered "non-cumulative" only in a restricted sense; small doses taken for long periods, result in accumulations in certain tissues; moreover, in the poison cases studied, the signs of arsenical poisoning continued for weeks, after the use of the beer was discontinued. Arsenic was found to be eliminated in the sweat, in the epidermic scales from the skin, in the nails, and especially in the hair. A special study was made of the last, and a large number of analyses made of the hair of patients who had been poisoned, and of others taking arsenic in a medicinal way. In thirty-eight cases where no arsenic had been taken, the hair showed no more than I/I 50 grain per pound. Patients who had taken $\mathrm{I} / \mathrm{I}$ o grain arsenic daily for two months, showed from $\mathrm{I} / 20$ to $\mathrm{I} / 5$ grain per pound in the hair. The report shows the necessity of excluding even small amounts of arsenic from food and drinks. 
A large part of the report deals with the tests and methods of analysis for arsenic in food products. As a rapid and somewhat rough method, the Reinsch test had been employed, but was not to be used for minute traces. The method of generating the hydrogen electrolytically, for converting the arsenic into hydrogen arsenide is recommended when current is available; but the Marsh-Berzelius method, with zinc and hydrochloric acid, is also advocated. The difficulty of getting pure zinc which will not form hydrogen arsenide, is remarked upon. It is stated that quantities of arsenic as small as 0.002 milligram, or $1 / 720$ of a grain, per pound, can be estimated, and smaller quantities detected, to $1 / 1000$ or $1 / 1300$ grain. The destruction of all the organic matter in beer or wort, is advised for the Marsh test; this is not necessary for the electrolytic method. Details of working the apparatus, and the precautions to be taken, are carefully prescribed, together with methods for determining arsenic in coal and fuels. The occurrence of arsenic in yeast, hops, malt, kilned barley, and in anthracite coal and coke used in drying malt, is to be guarded against. A long list of food articles in which arsenic may be present, with a short account in each case of the way it may have been introduced, and the quantities that were found, is included; also the precautions which should be taken by manufacturers to exclude arsenic from their products. A statement of the official control which should be provided by legislation, over the purity of food with reference to arsenic, is given in the report. The net result of the whole investigation is to show that food contamination by arsenic, can usually be traced back to sulphuric acid or to fuel, used at various points in the manufacture. A long discussion by numerous chemists follows the abstract, and throws much light on many of the points raised. Trotman ( $J$. Soc. Chem. Ind., I9O4 (I77)) describes a modified form of electrolytic method for arsenic-testing (see previous abstract). Seyfferth (Chem. Centrbl., I904 (I), 472) finds the use of chloroform in cases of inhalation of nitrous fumes, to be very beneficial, when administered in doses of 0.045 to 0.078 gram every ten minutes, until about 0.5 gram has been administered.

Foods.- There has been considerable reference to bleaching methods for flour in the trade papers dealing with milling interests, during the past year or two, and probably there has been some extension of this industry very recently. That any material benefit can accrue to the consumer by these processes seems questionable, and investigations along this line are very desirable. Balland (Compt. Rend., I904 (139), 822) examined some flour which had been bleached by ozonized air, with a view to determining the changes produced. Although the color was lighter than the untreated flour, the odor had become unpleasant, and there was a noticeable loss of flavor, owing to the fats having become slightly rancid. There was an increase of free acidity from 0.0147 per 
cent. in the untreated flour, to 0.0196 per cent., and free fatty acids were extracted with absolute alcohol. Fletrent (Compt. Rend., I904 (I 39), 945) states that three methods of bleaching flour, are in use: with ozonized air, with air and nitrogen peroxide, prepared by chemical means, and with air and nitrogen oxides produced by spark discharges. The author holds that the effect of these substances on the fats, acidity, diastase and micro-organisms of the flour, is beneficial, and improve its keeping qualities (see above abstract).

Stgar.-Gurwitsch (Ztschr. Ver. deutsch, Zuckerind., I904, IOI3) discusses at considerable length the uses of electrolysis in sugar manufacture. He regards electrical methods of purification as more promising for treatment of the molasses than for the original juice or syrup, and at best, only three methods seem promising: (I) the addition of lead saccharate or other basic salt, to the anode; (2) the use of a mercury cathode to take up alkali metals; (3) the use of two diaphragms. He also (Loc. cit., IO45) tried the purification of molasses by diluting largely and electrolyzing, using an iron cathode whose surface is wet with amalgam. The iron anode is partitioned off by a parchment paper septum and a 5 per cent. calcium chloride solution is used in the compartment. The iron in the anode liquor is precipitated by milk of lime, added continually. After electrolysis, the calcium saccharate in the molasses is decomposed with carbon dioxide. Von Lippmann (Ztschr. Ver. deutsch. Zuckerind., I903 (5.3), i I3I) discusses the losses of sugar in the refinery. He finds that during boiling, a certian amount of sugar is converted into stable bodies, remaining in the syrup, and also into volatile products, such as furfural, acetone, formic and acetic acids, which pass off with the condenser water. Thus in an instance cited, he found 0.75 per cent. of "non-demonstrable" loss, due to chemical changes. Winter (French Patent No. 3338I3) proposes to make products from beet-sugar which shall have the peculiar flavor of raw cane-sugar, by treating refined beet-sugar with a syrup containing invert sugar and products formed by treating invert sugar with alkalies at fairly high temperatures. Caustic alkalies work best for this, but any alkaline substance can be used. The heating must not be prolonged until caramel is formed.

Fermentation, Brewing, Etc.-Van Hest (Ztschr.ges. Brauw, I903 (26), 6I4, 70I, 787) has published extended investigations upon yeasts. Good top fermentation yeast does not increase the nitrogen content of the wort, but poor yeast does. He found some enzyme action in the case of dead yeast, or where no cell reproduction was noticed, whereby loss of extract in the wort resulted, this being greater than in the case where the yeast remained alive. The zymase present in one liter of yeast cells, is capable of fermenting 8 yo grams of sugar. The use of sterilized water for washing the yeast is advocated, as the author found the 
flocculent yeast sediment carried down most of the bacteria in the water. Excessive washing tends to extract too much of the nitrogenous matter from the yeast. The concentration or number of yeast cells per liter may fluctuate in those cases where top yeast is skimmed off and used for subsequent fermentation, especially if the yeast is washed and allowed to settle after skimming. A formula for the calculation of the quantity of any particular sample of yeast necessary to add to the desired volume of wort, is given, which is based upon a certain standard proportion of yeast of definite number of cells per liter. Seifert (Ztschr. landw. Vers. Wes. Ost, 6, 738) has studied a certain "disease" of currant wine, in which turbidity, a decrease of acidity and the acquisition of a harsh taste, were the phenomena noted. Bacteria capable of decomposing the citric acid into acetic acid, water and carbon dioxide, were found in the scum formed; the malic acid also appeared to be converted into lactic acid. The same bacteria are also found in grape wines. The author recommends sulphuring the wine after fermentation, as a protection. Barbier, in a French patent (No. 334071, I903), proposes to make vinegar from skim milk, by adding sugar, neutralizing the lactic acid with calcium carbonate, and fermenting with yeast to form alcohol. The alcoholic liquid is then infected with the acetic acid ferment, Mycoderma aceti, and after acetification is filtered on wood charcoal. Lindner and Matthes (Ztschr. Spiritusind., I903 (26), 545) describe a disinfectant obtained from by-products of the pottery industry, which they call "montanin." It consists essentially of hydrofluosilicic acid, and is claimed to have no action on the vessels of copper or tin, or on the vat coatings of pitch or lacquer, but it dissolves and disintegrates scale, and prevents growth of micro-organisms and mold. Rayman and Kries (Woch. Brau., I904 (2I), 24) have concluded a series of investigations, begun some years ago, as to the origin of amyl alcohol in fermented liquids. They show that pure cultures of yeast will, under certain circumstances, produce the alcohol, and that bacteria or unhealthy yeast are not the cause. Artificial glucose, fermented with pure yeast, gave no amyl alcohol, but a barley malt decoction yielded it every time. Mixtures of glucose with peptones, when fermented, did not yield the alcohol, nor did beet juice. It is concluded that the carbohydrates accompanying the hexoses were the source of the alcohol. These are supposed to be of the same order as Tollens' "furfuroids," obtained by the hydrolysis of brewers' grains with acids. Windisch (Woch. Brau., I9O4 (2I), 93), from a study of the cause of albumen or "gluten" turbidity in beer, concludes that it is due to the separation of tin or other metallic compounds of the albuminoids, formed during the filtration of the beer; it is especially noticeable just after the filter has been cleaned, the removal of the beer scale leaving the metal exposed to the beer. Filters with internal enamel, and 
horse-hair instead of brass-wire sieves, are recommended. Büchner and Meissenheimer (Ber. d. chem. Ges., I9O4 (37), 4I7) have examined the conditions under which lactic and acetic acids are formed in alcoholic fermentation with the expressed juice of yeast cells. Determinations of these acids in the juice, before and after fermentation, showed that the quantity varied in different experiments. In some cases, the lactic acid in the juice disappeared on keeping, and further additions of lactic acid to the juice also disappeared. In other cases, the lactic acid increased. As no sugar was present, it is supposed that the lactic acid was produced from the glycogen. Additions of cane-sugar increased the quantity of lactic acid formed, in most cases. The physiological condition of the yeasts at the time the juice was extracted, is supposed to account for the variations found; zymase probably contains two enzymes, one converting sugar to lactic acid, the other converting lactic acid to alcohol and carbon dioxide. The first is secreted by the lactic acid bacteria, but not the other; but yeast secretes both enzymes. Thus yeast-cell fermentations are of both kinds of enzyme action, and only the final products, alcohol and carbon dioxide, are observed. But with cell juice, as no continuous secretion of enzymes takes place, the final products will depend upon that enzyme which happens to be in excess at the time the extract is made. The authors conclude that lactic acid is only an intermediate product in alcoholic fermentations: glucose is supposed to split into two molecules of lactic acid, which is then hydrolyzed to form ethyl alcohol and carbon dioxide. Acetic acid was formed in the juice on standing for four days, and the amount increased when sugar was added to the juice. Schönfeld (Woch. Brau., I904 (21), 133) experimented with tin chloride as a cause of turbidity in beer. He found that 0.0005 gram per liter produced much turbidity after twenty-four hours. Strips of aluminum, copper, nickel, brass and antimony, placed in beer, had no effect in seven days, but tin caused turbidity after twenty-four hours, and the action became more marked on longer exposure. Tinned copper and other metals so coated, were more active than pure tin itself, and the conclusion reached is that tinned metals are unsafe to use about any of the brewery fittings. Sellenscheidt (Woch. Brau., I 904 (2I), 144) finds that any metal may cause turbidity in beer (see above abstract), but zinc and lead are most active; the marked action of tin is said to be due to lead alloyed with it. Galvanic action is more liable to cause turbidity than direct action of the beer on the metal; aluminum is particularly sensitive to galvanic corrosion. Pure tin is considered the best metal for filter-bodies, as it is less subject to galvanic corrosion; silver plate on brass is too expensive. Soda and other cleansing agents are almost sure to cause turbidity the first time the apparatus is used after their application; after any such cleaning the apparatus 
should be left full of stale beer over night, and then washed well with hot water. Low-grade asbestos pulp, used for filters, also causes a turbidity which is very hard to remove. Mohr (Woch. Brau., I904, (2 I ) I49), from a study of solution of peptone, concludes that the "head" retaining property of beer, bears no relation to its viscosity. The presence of suspended particles of colloid bodies in an exceedingly fine state of division, is assigned as the cause. The agglomeration of these fine particles (causing turbidity) reduces the permanence of the "head." Windisch (Woch. Brau., 1904 (21), I94) adds to the above statement certain instances where filtration has caused noticeable deterioration in the quality of the beer. He also thinks that the removal of the colloid bodies may injure the flavor, as well as reduce the headretaining property. He asserts that the attempt to get exceedingly clear beers has increased the ratio of metal surfaces and filter exposed to the total volume of the beer. Ludwig agrees with the other writers, but adds that the trouble may be due to the very heavy pressures used in filtering, causing solution of certain impurities in the sludge affecting the taste. Heinzelmann (Ztschr. Spiritusind., I9O4 (27), 95) has tested the extractive action of alcohol of various strengths, upon oak wood shavings. The non-volatile matter extracted increased, as the alcohol was more dilute. Previous boiling out of the wood in water, assisted the extraction, by the alcohol. Gelatin, as used to coat the interior of casks, is quite insoluble in 95 per cent. alcohol, but o. I gram per liter dissolved in 90 per cent. alcohol, and 0.25 gram per liter in 86 per cent. alcohol. It is not advisable to put crude alcohol of 90 per cent. or less into glued casks. Brand (Ztschr. ges. Brauw., I 904 (27), II 5) has examined the action of commercial ammonium fluoride $\left(\mathrm{NH}_{4} \mathrm{~F} . \mathrm{HF}\right)$ on rubber tubing, as used for disinfecting in breweries. He found that the usual i per cent. solutions employed, probably have no injurious action on the rubber, but it may be that badly compounded rubber would show some injury, owing to the action of the acid on the loading materials. Duchemin (Rev. Gen. de Chim., March, 1904) considers a wood distillation product, containing about 65 per cent. methyl alcohol, and having a specific gravity of 0.83 , as the best denaturating material for alcohol. About ro per cent. of this material is used. It does not clog the wicks of the spirit lamps nor give a bad odor when burned, but it has a very disagreeable taste, and cannot be separated from the alcohol. Bonnet has patented in France (No. 339460) certain artificial enzymes, made by adding manganese, iron or copper salts, to albuminous substances, such as gelatine, white of egg, or serum, or to colloids like gum, dextrin, etc., in the presence of a little alkali or alkaline salt, capable of preventing the precipitation of the metallic hydroxide. The material thus formed, acts as a carrier of oxygen, similar to the action of oxidizing enzymes. The material may be sterilized by 
heating, or obtained as a solid by precipitation with alcohol, and still retain its oxidizing property. Heinzelmann ( $Z$ tschr. Spiritusind., I904 (27), 399) states that denaturated alcohol of 9o per cent. strength, has more or less solvent action on some metals, especially lead and zinc; iron is less attacked, but in time some oxidation takes place, with some separation of a brown sediment. Copper and brass yield a greenish or bluish color to the liquor, and copper salts remain in the residue after evaporation. Tin seems to withstand all attack, and is recommended as most suitable for this use; tinned iron is especially good, if not abraded. Cement yields a yellow color and lime salts, to the denaturated alcohol. The crude methyl alcohol is supposed to cause most of the corrosion of the metals. Seifert and Reisch (Ztschr. Spiritusind., I904 $(27), 44 \mathrm{I})$ find that glycerol is produced in largest quantity during the earlier and most active periods of the alcoholic fermentation of grape must. Glycerol is considered as a metabolic product of the yeast, and the vigor and character of the yeast determines the quantity of glycerol formed. Excess of alcohol tends to retard or stop the formation of glycerol, since it also weakens the yeast growth. Emmerling (Ber. d. chem. Ges., 1904, (37) 3535) finds that very little fusel oil is formed, if all conditions of the alcoholic fermentation are normal, and the wort is pure. Numerous species of bacteria, some of which are found on the skins of the potato, cause the formation of amyl alcohol. Only under anaerobic conditions is the fusel oil formation active. A fermentation of wheat starch and of molasses, when infected with potato skins, vielded much fusel oil, but when converted with malt or inverted with acid, only a trace of fusel oil was produced on fermentation; addition of nitrogenous matter did not increase the production of fusel oil.

BlEAching, Dyes, ETC.-Fraass (Farber-Ztg., I9O4 (15), 69) considers the cost of electrolytic bleaching by the Schuckert apparatus. Allowing 2000 liters of solution with 2.5 to 2.7 grams available chlorine per liter as required to bleach 500 kilos of goods he finds that a similar amount of liquor can be produced in this apparatus at a cost of 3.88 marks, which he considers a good showing, against the bleach solution made from bleaching-powder. The items of cost are: 29 kilos salt at 0.64 mark; power, 40 amperes at I Io volts, for nine hours, or 39.6 kilowatt hours, at 1.98 marks; depreciation and insurance on plant, at I.I6 marks per day; and sulphuric acid, at o. Io mark. Breaudat (Rev. Gen. Mat. Col., I 903 (7) 357), in a review of the manufacture of natural indigo in British India, states that bad water is one of the chief obstacles. It is improved by treatment with lime and filtration through sand. He also finds that rapid drying of the indigo affords a product which titrates some i 5 to 18 per cent. more indigotine with permanganate, than a slowly dried sample. The author gives no explanation of this, but is of the opinion that neither micro- 
organisms nor oxidation by the air, can account for the loss by slow drying. He obtained a black residue of nitrogenous matter, soluble in fuming sulphuric acid, from a low-grade (50 per cent.) indigo, by extracting with water, which he believes is a compound of indigotine, which reduces permanganate. Will and ToecheMittler (Ber. d. chem. Ges., I9O3 (36), 4390) have published an improved method of making chloranil from $p$-nitraniline, by treatment with potassium chlorate, to form $1,2,6,4$,-dichlor- $p$ nitraniline. This is recrystallized from glacial acetic acid, and then reduced by treatment with tin and hydrochloric acid, whereby 2,6-dichlor-p-phenylene diamine is formed, which yields chloranil when potassium chlorate is added to the boiling, strongly acid, solution. By recrystallizing from toluene, a product melting at $285^{\circ}-286^{\circ} \mathrm{C}$. is obtained. A yield of 90 per cent. of the theoretical is claimed. Green and Steven have found that formic acid is the best substitute for sulphuric acid, in dyeing mixed cotton and wool goods. It yields faster colors than acetic acid and does not tender the cotton so much as sulphuric acid. The price is not an obstacle. Ehrlich and Sachs (Ber. d. chem. Ges., I903 (36), 4296) find that by treating an ethereal solution of ethyl bromide with magnesium powder and then adding to the decanted liquid, an ethereal solution of bromo-dimethylaniline, they form dimethylaminophenylmagnesium bromide. This, in solution, yields various triphenylmethane dyestuffs, by treatment with Michler's ketone, benzophenone, ethyl benzoate or ethyl naphthonate and similar substances. (Methyl violet, malachite green, etc., are so obtained.) Alliston (Bull. Soc. Ind., Mulhouse, I903 (73), 346) recommends "Hydrosulphite NF" as a means for bleaching the whites of calicoes printed with insoluble azo dyes, where bleachingpowder injures the colors. Hydrosulphite $\mathrm{NF}$ is the condensation product of formaldehyde and sodium hydrosulphite; the latter is too easily decomposed for use in this way. Knecht (Ber. d. chem. Ges., I904 (37), 3479) has determined the quantities of various acid dyes of similar constitution, taken up by wool from baths containing sulphuric acid. He finds that a proportional relation exists between the molecular weight of the dye and the quantity taken up, if the conditions remain unchanged. Large variations in the quantity of dyestuffs used, and of the water in the bath had no material effect on the amount taken up by the fiber. The author discredits the solution theory, and sustains the chemical theory of dyeing. Lob (Ztschr. Elektrochem., I904 (I0), 237) prepares azo dyes electrolytically by passing a current through neutral mixtures of aromatic amines, sodium nitrite and a substance, usually a phenol, to combine with the diazo-compound formed. The mixture is put into the anode compartment and a diaphragm is used. The electrodes must not be attacked. He makes Orange II, from sodium sulphanilate and $\beta$-naphthol; Congo red, from benzidine and sodium naphthionate; Chrys- 
amine $\mathrm{G}$, from benzidine and sodium salicylate, etc.; Dianisidine blue from dianisidine and $\beta$-naphthol. Schmidlin (Compt. Rend., I904 (139), 87I), from a study of rosaniline derivatives, considers the cause of coloring properties in dysetuffs, to be the presence of a strongly exothermic group in the molecule, which influences the formation of an endothermic group, containing double bonds, at some other part of the molecule; thus one part of the molecule may be set in vibration by the light waves having a certain wave period. The exothermic groups would correspond to the auxochrome groups of Witt's theory, and the endothermic groups to the chromophores. He supports his theory by citing Helmholtz' hypothesis of absorption, which assumes that a molecule may have central fixed portions and mobile portions, usually in positions of equilibrium with the fixed parts; in cases of absorption, the wave-motion energy is transferred into heat by friction within the molecules, between the fixed and mobile parts. The exothermic and endothermic parts correspond to the fixed and mobile portions assumed by Helmholtz. The Badische Anilin u. Soda Fabrik has taken a French Patent (No. 344680), for making artificial alizarin by heating a mixture of anthraquinone with very concentrated caustic potash-soda solution, and an oxidizing agent, such as sodium chlorate, to $200^{\circ} \mathrm{C}$., in open vessels, while stirring thoroughly. The product is extracted with water, and air blown into the solution, while milk of lime is added to precipitate the alizarin. The alizarin is separated from the precipitate, and freed from anthraquinone by treating with hydrochloric acid, and then extracting the residue with dilute caustic soda solution, which dissolves the alizarin.

Cellulose.-De Mosenthal ( $J$. Soc. Chem. Ind., I904, 292) has studied the effect of solvents on cotton and nitrated cotton. His study of the fiber with the microscope, shows the inter-cuticular substance to be made up of minute spherical granules, which lie closely packed and kept in place by the cuticle. He regards the action of cotton upon polarized light as mainly due to tension strains in the layers. The cuticle is stated to contain stomata, and to show distinct porosity when examined under magnification of 1,000 diameters. The stomata lie in oblique rows and appear to lead to lateral channels. The penetration of dyes and mordants into the fiber was ascribed by Walter Crum, to an osmotic action of the cuticle, and the author supports this view. He does not consider capillarity as of much effect in dyeing, his experiments tending to show that it does not take place with single fibers. Nitration produces but little apparent change, but in polarized light it appears that the relative tension of the layers has decreased. The outer cuticle appears more wrinkled. The solvent actions of zinc chloride and ammoniacal cupric oxide are considered to be different; the former destroys the structure, but in the restored cellulose from the latter solution, the intracellular granules 
are preserved, and some fragments of the cuticle can be found. Acetone appears to be the only general solvent for nitrated cotton; as a rule, the solubility of the nitrocellulose is not a function of the nitration. The existence of di-, tri-, tetra-, etc., nitrated cotton, is doubted. The viscosity of solutions of nitrated cellulose prepared under different conditions, was found to vary even though the nitrogen percentage was the same in each. Solutions in acetone were evaporated and the granules were seen. A solution of about I per cent. can be, to a considerable extent, passed through a Pasteur filter, and if such filtered solution containing granules, is poured into water, the precipitate is a fine powder. A long list of various solvents proposed in patents, is given. In addenda, the author states that he has dialyzed a 5 per cent. solution of nitrated cotton, through a parchment diaphragm. Knecht (Ber. d. chem. Ges., I9O4 (37), 549) finds that cotton, nitrated with acid of I.4I5 specific gravity, takes a gelatinous appearance, but when washed and dried, the original appearance is restored though a shrinkage of $\mathrm{I} 3$ per cent. has occurred. The cotton then shows many of the properties of a mercerized cotton; it has greater affinity for dyes, is stronger, and contains some moisture. By pressing the damp nitrated cotton, to remove the acid, and drying in vacuo over lime, the product is unstable, fumes in moist air, and yields nitric acid and cellulose hydrate when digested with water. In dry heat, at $100^{\circ} \mathrm{C}$., in vacuo, red fumes are set free and a substance is formed, closely resembling oxycellulose. The shrinkage seems to bear some relation to the amount of nitric acid combined with the cellulose, which is also influenced by the strength of acid used. Acid stronger than I.4I5 forms ordinary nitrocellulose. The author thinks the unstable body is a cellulose nitrate, $\mathrm{C}_{6} \mathrm{H}_{10} \mathrm{O}_{5}-\mathrm{HNO}_{3}$. Flemming (Chem. Ztg., rgo4 (28), 2I3) finds that dichlorhydrin is ten times more powerful than amyl acetate as a solvent for nitrated cellulose, yielding a clear solution. Very concentrated solutions (Io grams in 50 grams solvent), when heated, decomposed somewhat with evolution of nitrous vapors, and the liquid became thinner. He also found that celluloid dissolves in the solvent with some loss of nitrous fumes, this loss diminishing after the solution becomes stronger; very concentrated solutions became solid when benzene, amyl acetate or epichlorhydrin were added; they mix readily with the fatty acids from linseed oil. Green (Farben. $u$. Textil-Chem., Igo4 (3), 97) proposes a formula for cellulose, corresponding to $\mathrm{C}_{6} \mathrm{H}_{10} \mathrm{O}_{5}$, and concludes that the fact of cellulose being a colloid, does not imply a high molecular weight. The formula suggested is

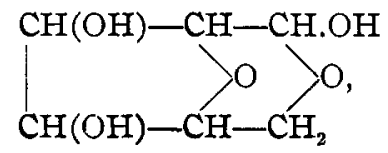


which would be an inner anhydride of glucose. This would explain the formation of glucose from cellulose by hydrolysis. Mercerization probably converts the inner oxygen atoms into $-\mathrm{ONa}$ groups, which then yield $\mathrm{OH}$ groups. Trinitrate and triacetate derivatives are possible, but tetra-compounds could only be formed after one of the inner oxygen atoms had been replaced by $\mathrm{OH}$. The formation of bromomethylfurfural from cellulose is also explained; thus, by hydration we get

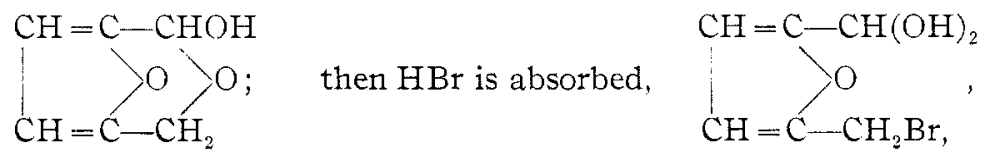

which splits out water, leaving<smiles>O=CC1C=CC(Br)=CC1Br</smiles>

Fibers and Textrues.-Stocks and White $(J$. Soc. Dyers and Colorists, I9O4 (20), 55) have a review of improvements in the sizing of textiles. Cassava root starch is promising as of much use in the future for sizing. By fermentation of flour the albuminoids become largely soluble, sugar is destroyed and free acid is found. This change is most noticeable in two weeks after the flour is prepared; later there is less change. As moulds and bacteria continue to grow the insoluble albuminoids become more noticeable. Fresh flour, if treated with 0.5 per cent. solution of acetic or lactic acid, has its albuminoids made soluble, and acquires the properties of fermented flour. To prevent mould growth a I per cent. solution of lactic acid is better than zinc chloride in stronger solution. Loverdo (Compt. Rend., I904 (I38), I434) proposes to kill the chrysalis of the silkworm by placing the silk-cocoons in chambers kept at temperatures below $0^{\circ} \mathrm{C}$. for a month. In this way the cocoons need no particular attention, and no injury results to the fiber, as may easily happen with the hot process.

Mercerizing.-Hübner and Pope ( $J$. Soc. Chem. Ind., I904, 404) have continued their studies of the effects of reagents upon the cellulose of the cotton fiber, and have examined the action of mercerizing and other liquids upon the luster, tinctorial properties and structure of cotton. It is shown that cold caustic soda considerably increases the affinity of cotton for direct dyes, and between $0^{\circ}$ and $18^{\circ} \mathrm{Tw}$, this increase is approximately proportional to the strength of caustic used; from $18^{\circ}$ to $22^{\circ} \mathrm{Tw}$. there is increase in the affinity developed in proportion to the strength of the caustic, and between $26^{\circ}$ and $30^{\circ} \mathrm{Tw}$. the most marked increase is found. Between $30^{\circ}$ and $65^{\circ} \mathrm{Tw}$. the affinity 
for the dye is slowly increased, but at $70^{\circ} \mathrm{Tw}$. the maximum is reached and stronger solutions cause a marked decrease in the affinity; thus with $80^{\circ} \mathrm{Tw}$. the affinity is no stronger than at $35^{\circ} \mathrm{Tw}$. Repeating the tests at temperatures of $20^{\circ}$ and $80^{\circ} \mathrm{C}$. it appears that the affinity decreases with the temperature rise as well as with the concentration. Trials were also made of the action of barium-merctric oxide, potassium iodide, hydrochloric acid, zinc chloride and nitric acid. The results of the dyeing trials showed that each of these substances causes increase of the affinity for the dye, but with these no reversing effect was found in the high concentrations. The shrinking effect of different concentrations of caustic soda was also examined, and after overcoming numerous difficulties it was found that even $\Upsilon^{\circ} \mathrm{Tw}$. caustic caused noticeably greater shrinkage than did pure water, and there was a uniform increase of shrinkage with the increase of concentration until $20^{\circ} \mathrm{Tw}$. was reached, at which strength a sudden increase in the amount of shrinkage occurred. This increases rapidly until a maximum effect was found, at $45^{\circ} \mathrm{Tw}$.; above this a decrease of shrinkage took place, but with the solutions above $50^{\circ} \mathrm{Tw}$. the viscosity of the liquid is such that in washing, the fiber becomes soaked with a more dilute caustic soda, which itself exerts a more marked shrinking effect. This made it necessary to measure the shrinkage of the yarn without previous washing and while still wet with the lye. The fact has a practical bearing in mercerizing operations; if a liquor of $50^{\circ} \mathrm{Tw}$. be used in the machine, the main shrinkage occurs during the impregnation and no additional strain comes on the goods or the machine during washing, but with liquors of $75^{\circ}$ or $80^{\circ} \mathrm{Tw}$. the greatest shrinkage occurs during the washing out of the caustic, which causes a certain tendency for the goods to tear at that time and which could be avoided by using weaker liquor. The effect on the microscopic appearance and structure of the cotton fiber of the various mercerizing reagents was carefully studied and several photographs are given illustrating these. The authors show that the liquids which cause luster act first to cause swelling and a gelatinous appearance in the fiber, second, a marked tendency to shrinkage, and third, an untwisting of the natural curl of the fiber. The swelling must precede the untwisting to obtain an increased luster. As the ends of the fibers are more or less firmly held the uncurling of a part of the swollen and stretched fiber causes the other portions of the same fiber to twist, perhaps in a reversed direction to each other, hence the appearance of a gelatinous rod, having a series of pieces of cork-screw-like windings, is produced. The original folded ribbon of the raw cotton becomes a straight rod, nearly circular in cross-section and having on its surface, spiral elevations with smooth, rounded edges. These ridges reflect the light from all directions and thus produce the increased luster. An experiment with smooth and twisted 
glass rods serves to illustrate the difference between cottons mercerized with and without tension. Beltzer (Monit. Scient., 1904 (18), 732) has reviewed the status of mercerizing as now practiced, dealing with the various operations of preparation, the various liquids used, the several types of apparatus and machines used; dyeing processes and examination of products; also calculations of the cost of the several operations.

PAPER.-Montant1s (Woch. Papierfabrik., I904 (35), 2832) reviews the recent changes in the processes of boiling wood for sulphite pulp. The time of boiling has been cut down more or less, but depends upon the strength of the liquor and the quality of pulp desired; for great strength "high boiling" is customary, the liquor having considerable sulphur dioxide still in solution at the end of the process, but if easily bleached pulp is required "low" boiling, in which nearly all the sulphur dioxide is used, is practiced. Such pulp is brown in color, but bleaches very easily, provided the wood is not scorched. Slow boiling is also essential. The same author (Loc. cit., 276I) also considers the bleaching of sulphite pulp; for full bleach about i 4 per cent. of bleaching-powder is needed. No acid is used and the temperature is kept under $40^{\circ} \mathrm{C}$. Bleaching is done in the hollander and for pulp that is difficult to decolorize, two treatments with bleaching solution are recommended, but the quantity of bleach used each time is less than would be used ordinarily in the engine. The liquors are used at $3.5^{\circ}$ to $4^{\circ}$ Bé,, but the available chlorine is best determined in each lot.

TANNING, LEATHER.-Eitner (Der Gerber, I904 (30), I73) examined certain specimens of chrome leather containing 5 per cent. of grease, which, on lying in contact with vegetable-tanned leather containing I 7 per cent. of grease, showed spueing or white spots at the points of contact. These spots were stearine crystals, which had passed through the chrome leather. It was not proved that they had passed from the vegetable-tanned leather goods to the chrome leather, but considering the colloid nature of the latter it might be possible that the crystallizable stearin has passed through as through a membrane. A case where magnesium sulphate, from the filling of the cloth lining, had passed through and appeared on the surface of boots is mentioned. It is concluded that stearin should not be used in fat-liquor for chrome leather, nor on light calf-skins.

Essentral Orls.-Heber (English Patent No. 10004, 1903) proposes to deodorize Russian oil of turpentine, petroleum spirit, benzene, etc., by treating with 5 to ro per cent. of its weight of a 4 per cent. solution of potassium permanganate. Chromic acid and persulphates are also claimed. Treatment with lime, and steam distillation should precede the treatment with the oxidizing agent. Von Soden and Treff (Ber. d. chem. Ges., I9O4 (37), 1094) find the alcohol nerol present in otto of roses to the extent 
of 5 to Io per cent. There is also about I per cent. of eugenol present. By fractionation in vacuum of these alcohols, an alcohol, $\mathrm{C}_{15} \mathrm{H}_{28} \mathrm{O}$, probably identical with the farnesol of the oil of acasia flowers, was obtained. This alcohol also is present in otto of roses to about I per cent. Power and Lees (Proc. Chem. Soc., I904 $(20), 88)$ have examined the oil of the California laurel, Umbellularia Californica. It has a specific gravity of 0.9483 at $16^{\circ} \mathrm{C}$.; in a Ioo mm. tube, $\alpha_{D}$ is $-22^{\circ}$; soluble in I.5 parts of 70 per cent. alcohol. The chief constituents are umbellulone (an unsaturated aromatic ketone), $\mathrm{C}_{10} \mathrm{H}_{14} \mathrm{O}$, some 60 per cent.; cineol, 20 per cent. ; eugenol methyl ether, Io per cent.; l-pinene, 6 per cent.; eugenol, I.7 per cent.; and traces of safrol.

INDIA RuBBER.-Weber (India Rubber Jour., I904 (27), 2 r, 3o) points out the possible danger from acid present in the sulphur used for vulcanizing, especially in goods containing no fillers of alkaline nature. Lime ground with sulphur in a ball-mill, is advocated as best for vulcanizing. The same writer, in another article (Gummi-Ztg., I903 (18), 255), shows that the adhesion between vulcanized rubber and metals, is firmer in proportion to the readiness with which sulphur combines with the metal. Thus copper, lead, silver, arsenic and antimony adhere readily to the rubber; tin, zinc, iron and aluminum less so; and platinum and gold not at all. Thus iron and steel are coated with copper or antimony when firm adhesion of the rubber is desired, while in the case of cables, the copper wire is usually tinned to avoid too tenacious adhesion. Weber (Gummi-Ztg., I904 (I 8), 46I) notes that the valuation of rubber by the method of fractional precipitation is not safe when used alone on unknown rubbers, and recommends an elementary analysis of the rubber, and also of the fractional precipitates with determinations of the bromine, as a control. An instance in which the method failed to give the true value, is cited. The same author (India-Rubber Jour., I904 (28), 228) describes the varieties and characteristics of Castilloa. The probable returns from its cultivation in Columbia are put at roo per cent. in the eighth year of growth of the trees. They should not be tapped earlier, since rubber from young trees contains too much resin. An improved process for coagulating the latex without coagulating the albumin, is to dilute it with five volumes of water, strain through cotton gauze, and then add 8 ounces of formaldehyde to each barrel of liquid. After agitation, the liquid is kept quiet for twenty-four hours, when the rubber collects on the surface as a solid, white cake, from which any traces of albumin can easily be washed. Harries (Ber. d. chem. Ges., I904 (37), 2708) finds that Para rubber dissolved in chloroform is attacked by ozone, and the ozonide formed, decomposes with hot water into keto- and dialdehydes, setting free hydrogen peroxide, which further oxidizes the aldehydes to acids. The ozone compound is obtained as a vitreous mass, after precipitation from its ethyl 
acetate solution by adding petroleum spirit. It explodes when heated on platinum foil. The composition corresponds to $\left(\mathrm{C}_{10} \mathrm{H}_{18} \mathrm{O}_{6}\right)_{x}$, the value of $x$ being uncertain, probably 2 or 3 . When thoroughly extracted with water, the extract was chiefly levulinic acid; oxalic acid was not detected, but it is thought to be a product of secondary oxidation of the rubber. Fendler (GummiZtg., 1904 (19), 41) has examined the reaction of solvents on rubber, using some twenty-six varieties in all. He fails to confirm Weber as to the insolubility of rubber in ether, but finds it, on the whole, a fairly good solvent for some varieties. Some rubbers contain substances insoluble in all solvents tried; these are supposed to be oxidation products, or substances formed by the sulphurous acid produced in coagulating the rubber in the smoke of Urikuri nuts. Petroleum spirit extracts the lower oxidation products, while the portions dissolved by benzene contain more oxygen. The author holds that Harries' "nitrosit" method estimates the partially oxidized products as pure rubber, and should be used only for vulcanized rubber.

\section{NEW BOOKS.}

Avogadro and Dalton The StandNg in Chemistry of Their HyPOTHESES BY ANDREW N. MELDRTM, D.SC. Edinburgh William F. Clay I904 Price, 3 shillings.

The chemist has to do with so overwhelming a multitude of facts that sufficient consideration of the principles and assumptions at the basis of the superstructure is not easy. The present interesting essay, whose preparation and printing have been aided by a grant from the Carnegie trustees, will be sure of a welcome. The author's purpose may be stated in his own words: "The theoretical basis of Nernst's system of chemistry is Avogadro's hypothesis. Nernst's book is a comprehensive one, suitable for the student of research. It goes as far as the debatable ground between the known and the unknown. It was doubtless far from Nernst's purpose to expatiate on the rudiments of chemistry. There is reason to believe that it would be of interest, and even of value, to trace the development, in logical order, of the cardinal doctrines of chemistry on the basis of Avogadro's hypothesis."

The first part of the essay contains seven chapters and treats of "the standing in chemistry of Avogadro's hypothesis." The second part, in the same number of chapters, treats of "the standing in chemistry of Dalton's atomic hypothesis." The conclusion of the first part is ( $I$ ) "that Avogadro's hypothesis may not be regarded as a well established truth," (2) "that Avogadro's 